\title{
The ammonite genera Fagesia and Neoptychites (family Vascoceratidae) in the Iberian Trough, Spain ${ }^{\S}$ Les genres d'ammonites Fagesia et Neoptychites (famille Vascoceratidae) dans le Bassin Ibérique (Espagne) Los géneros de ammonites Fagesia y Neoptychites
(familia Vascoceratidae) en el Surco Ibérico (España)
} Fernando Barroso-Barcenilla ${ }^{\mathrm{a}, \mathrm{b}, \mathrm{t}}$, Antonio Goy ${ }^{\mathrm{a}}$

a Departamento de Paleontología, Facultad de Ciencias Geológicas, Universidad Complutense de Madrid, 28040 Madrid, Spain

${ }^{\mathrm{b}}$ Departamento de Geología, Edificio de Ciencias, Universidad de Alcalá de Henares, 28871 Alcalá de Henares, Spain

\begin{abstract}
The ammonites assigned to the genera Fagesia Pervinquière, and Neoptychites Kossmat, of the Wiedmann (Tübingen, Germany) and Goy, Carretero and Meléndez (Madrid, Spain) collections obtained from the Iberian Trough have been revised. New mainly lower Turonian specimens of the species Fagesia catinus (Mantell), F. tevesthensis (Peron), F. rudra (Stoliczka), F. superstes (Kossmat), F. pachydiscoides Spath, and Neoptychites cephalotus (Courtiller) have also been presented. In addition we have described one new species: F. mortzestus. Studies of the morphologies and the geographical and stratigraphical distributions of all these species have led to the identification of several phylogenetic relationships between them, and to distinguishing one main phase in the evolution of the family Vascoceratidae Douvillé, characterised by the dominance of Fagesia with Neoptychites.
\end{abstract}

Résumé

Ce travail présente une révision des ammonites des collections Wiedmann (Tübingen, Allemagne) et Goy, Carretero et Meléndez (Madrid, Espagne) qui proviennent du Bassin Ibérique et qui ont été assignées aux genres Fagesia Pervinquière et Neoptychites Kossmat. Sont également présentés de nouveaux exemplaires, majoritairement du Turonien inférieur, attribués aux espèces Fagesia catinus (Mantell), F. tevesthensis (Péron), F.rudra (Stoliczka), F. superstes (Kossmat), F. pachydiscoides Spath et Neoptychites cephalotus (Courtiller). Nous avons également décrit une nouvelle espèce : F. mortzestus. L'étude morphologique et les distributions géographiques et temporelles de ces espèces ont permis de les situer d'un point de vue phylogénétique et de distinguer une étape principale dans l'évolution de la famille Vascoceratidae Douvillé, caractérisée par la dominance de Fagesia avec Neoptychites.

\#2008Elsevier Masson SAS. All rights reserved.

Resumen

En este trabajo se ha desarrollado una revisión de los ammonites de las colecciones Wiedmann (Tübingen, Alemania) y Goy, Carretero y Meléndez (Madrid, España) procedentes del Surco Ibérico y asignados a los géneros Fagesia Pervinquière, y Neoptychites Kossmat. Se han presentado nuevos ejemplares, en su mayoría del Turoniense inferior, atribuidos a Fagesia catinus (Mantell), F. tevesthensis (Peron), F. rudra

\footnotetext{
${ }^{\S}$ Corresponding editor: Pierre Hantzpergue.

* Corresponding author.

E-mail address: fbarroso@geo.ucm.es (F. Barroso-Barcenilla).
} 
(Stoliczka), F. superstes (Kossmat), F.pachydiscoides Spath, y Neoptychites cephalotus (Courtiller). Igualmente, se ha descrito una nueva especie: F.mortzestus. El estudio de las morfologías y las distribuciones geográficas y temporales de estas especies ha permitido la identificación de varias líneas filogenéticas y de una etapa principal en la evolución de la familia Vascoceratidae Douvillé, caracterizada por el dominio de Fagesia con Neoptychites.

\#2008 Elsevier Masson SAS. All rights reserved.

Keywords: Upper Cenomanian; Lower Turonian; Ammonoidea; Vascoceratidae; New species; Iberian Trough

Mots clés : Cénomanien supérieur ; Turonien inférieur ; Ammonoidea; Vascoceratidae ; Nouvelle espèce ; Bassin Ibérique

Palabras clave : Cenomaniense superior; Turoniense inferior; Ammonoidea; Vascoceratidae; Nueva especie; Surco Ibérico

\section{Introduction}

This paper firstly presents a revision of the ammonites assigned to the genera Fagesia Pervinquière, 1907, and Neoptychites Kossmat, 1895, from the Iberian Trough that are held in the Universität Tübingen (UT, Germany) and the Universidad Complutense de Madrid (UCM, Spain). These centresholdtheWiedmann(JW), Goy(AG), Carretero(CM) and Meléndez $(\mathrm{MH})$ palaeontological collections, which include most of the specimens of the family Vascoceratidae Douvillé, 1912, from this palaeogeographical region. Secondly, a detailed taxonomic analysis has been made of the members of these genera obtained during field works carried out for this investigation. The field works took place in the upper Cenomanian and lower Turonian outcrops situated in the localities of Puentedey (PU) and Soncillo (PS), in the north of the province ofBurgos, of Fuentetoba(FT), inthe centre of Soria, and of Cantalojas (CC), Galve de Sorbe (CG), Condemios (CA; $\mathrm{CB}$ ), Somolinos (CS) and Tamajón (TA), in the north of Guadalajara, Spain (Fig. 1). Thirdly, the information obtained has made it possible to reach several conclusions concerning the taxonomy, distribution and evolution of the Vascoceratidae.

In order to establish a more precise systematic classification of the analysed taxa, we have also studied the original types attributed to this family that are held in the Museu do Instituto Geológico e Mineiro de Lisboa, Portugal, and in the MNHN Paris, France.

From a stratigraphical point of view, the ammonites presented herein have been mainly collected from the Margas

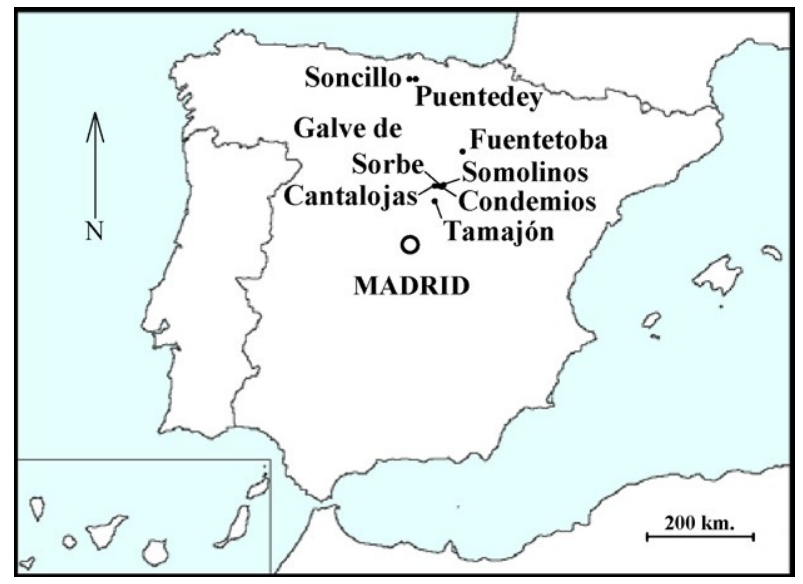

Fig. 1. Geographic origin of the specimens presented in this paper. de Puentedey (Floquetetal., 1982) and Margas de Picofrentes (Floquet et al., 1982) formations, deposited respectively in the inner and in the marginal environments of the platform. These formations are remarkable for containing the most complete and characteristic marls of the studied interval in the north and centre of Spain, as pointed out by Wiedmann (1960a, 1964, 1975a, 1975b, 1979), Wiedmann and Kauffman (1978), Floquet et al. (1982), Floquet (1991), Santamaría-Zabala $(1991,1992,1995)$ and Segura et al. (1993), among others. The study of these formations is highly suitable, as the biostratigraphic and taxonomic information obtained from them allows inferring the evolutionary pattern followed by the Vascoceratidae during the early Turonian in the Iberian Trough.

\section{Historical background}

From the beginning of the 20th century many cephalopods have been collected from the upper Cenomanian and lower Turonian, not only in the Iberian Trough but in the whole of Spain, and assigned to the family Vascoceratidae Douvillé, 1912, by several authors. However, only a few detailed taxonomic studies of them have ever been carried out, since only a few of these specimens have been described and illustrated in an appropriate way. Among the first systematic analysis concerning the palaeontology of the upper Cenomanian and lower Turonian cephalopods in the Iberian Trough, that of Karrenberg (1935) was the most outstanding. This author described in the Outer Navarro-Cantabrian Platform and the North-Castilian Sector many new species and mentioned several taxa, some of which can be attributed to the genus Neoptychites Kossmat, 1895.

After collecting and studying a large number of cephalopods from the Upper Cretaceous of the Iberian Trough, Wiedmann (1960a, 1964) identified numerous ammonites. He described several new taxa in the Outer Navarro-Cantabrian Platform and the North-Castilian and Central sectors. Among the obtained specimens, many of them from Puentedey, Fuentetoba or Somolinos, this author cited a significant number of representatives of Fagesia Pervinquière, 1907, and Neoptychites. Based on the ammonite sequences obtained during his field works containing several members of the latter genus, Wiedmann (1975a) proposed somenewtaxaintheUpper Cretaceous of the Central Sector. In the Outer Navarro-Cantabrian Platform, the North Castilian Sector and the La Demanda Area, Wiedmann and Kauffman (1978) and Wiedmann (1979) identified a large number of ammonites attributed to Fagesia and Neoptychites. 
Based on a detailed analysis of the ammonites obtained in Condemios, Somolinos and Tamajón, Meléndez-Hevia (1984) identified an important number of species, several of them belonging to the former genus. Lamolda et al. (1989) reported some members of Fagesia in the Turonian of the Outer Navarro-Cantabrian Platform. Floquet (1991) analysed the Upper Cretaceous geology of the northern half of the Iberian Trough and of the Basque Basin, in the north of Spain, and cited a significant number of cephalopods, including somemembers of these two genera, although he did not provide any figures of them.

Santamaría-Zabala (1991, 1992, 1995) studied the upper Cenomanian to Santonian ammonites from the Outer Navarro-Cantabrian Platform and the North-Castilian Sector, and identified several representatives of Fagesia. Taking into account the ammonites studied by this author and additional information, Martínez et al. (1996) cited the cephalopod taxa, among them several species of this genus, collected from the upper Cenomanian to Santonian of the Basque Basin, the Outer Navarro-Cantabrian Platform and the North-Castilian Sector. Lamolda et al. (1997) analysed the Cenomanian-Turonian boundary in the Outer Navarro-Cantabrian Platform, where they obtained some members of Fagesia. In the relatively deep-sea originating series of the Outer Navarro-Cantabrian Platform, Küchler (1998) recognised some ammonites attributed to this genus.

Recently, Barroso-Barcenilla (2004) studied the Acanthoceratidae and the cephalopod sequence from the upper Cenomanian and lower Turonian in the northern margin of the North-Castilian Sector, identifying several members of the Fagesia and Neoptychites. The palaeontological data obtained in this work were contrasted with the ones reached in the North-Castilian Sector and other regions of the Iberian Trough by Barroso-Barcenilla (2006), and the conclusions on the genera of the carried out research have been exposed in the presentpaper.

Other relevant contributions to the knowledge of the taxonomy and the biostratigraphy of the upper Cenomanian and lower Turonian cephalopods in the Iberian Trough were made by some authors, such as Wiedmann (1960b, 1962, 1975b), Mojica and Wiedmann (1977), Carretero-Moreno (1982), Segura and Wiedmann (1982), López and SantamaríaZabala (1992), Gräfe and Wiedmann (1993), Segura et al. (1993), Gräfe (1994), Santamaría-Zabala and López (1996), Barroso-Barcenilla (2007) and Barroso-Barcenilla and Goy (2007).

Likewise, in the last years several biostratigraphic investigations were carried out in other palaeogeographical regions adjoining to the Iberian Trough, and closely related to it, in which Upper Cretaceous cephalopod sequences were identifi . Among these works, those by Wiese $(1995,1996$, 1997), Wilmsen (1996, 1997a, 1997b, 2000), Wilmsen and Wiese (1996) and Wiese and Wilmsen (1999) in the North-Cantabrian Basin, and by Martínez (1982) in the Pyrenean Basin, both located in the north of Spain, may be cited.
3. Revision of the Fagesia and Neoptychites (Vascoceratidae) from the Iberian Trough held in the collections of the UT and the UCM

At the present time, the JW, AG, CM and MH collection of the UT and the UCM together contain the largest number of representatives of the family Vascoceratidae Douvillé, 1912, so far collected from the upper Cenomanian and lower Turonian of the Iberian Trough. However, it has not been possible to find specimens of all the members of the genera Fagesia Pervinquière, 1907, and Neoptychites Kossmat, 1895, cited in the works of Wiedmann (1960a, 1964, 1975a, 1979) and Wiedmann and Kauffman (1978) in the UT. The present investigation is based exclusively on specimens that are now hosted in the JW collection, which is why not all the representatives of these two genera mentioned in the publications of the German investigator have been revised. Likewise, it is important to indicate that the method by which the fossils of the CM collection have been numbered and identified has hindered an adequate and individualized tracking of its ammonites. Therefore, the revision of the taxa cited by Carretero-Moreno (1982) has only been partially carried out, and as a result the references to herworkin the synonymy of the systematic section are imprecise.

In the present paper, the palaeogeographical division (Fig. 2) and the ammonite zonation (Fig. 3) for the upper Cenomanian and lower Turonian of the Iberian Trough proposed by BarrosoBarcenilla et al. (2008) have been followed. These authors defined several biostratigraphic units, and correlated them with ones previously recognized in the same region by other investigators, and with the standard zones.

Concerning the numeration of Wiedmann's biostratigraphic units mentioned in the present paper, a modification was made between the first and the latter works of this author. Wiedmann $(1960 a, 1964)$ considered that the Cenomanian-Turonian boundary was located between the Metoicoceras muelleri and the Metoicoceras swallowi zones. Therefore, the latter was considered as the first biostratigraphic unit of the upper stage. The location of the boundary was later modified by Wiedmann and Kauffman (1978) and Wiedmann (1979). They held the opinion that the beginning of the Turonian coincided with the appearance of the genus Vascoceras Choffat, 1898. On the basis of this new premise, the Vascoceras gamai zone was the oldest Turonian, which is why these authors began the enumeration of their biostratigraphic divisions from this unit. In order to avoid possible confusions, all references made in this paper to Wiedmann's biostratigraphic zones allude to his most recent works.

\subsection{Fagesia Pervinquière, 1907}

Wiedmann (1960a, 1964) stated that all his specimens assigned to species of the genus Fagesia were collected from his middle Turonian zone $\mathrm{T} \mathrm{VI}$, which he named of Neoptychites and Pseudaspidoceras. This stratigraphical distribution however seems to be too high, and Wiedmann and Kauffman (1978) and Wiedmann (1979) modified it. They 


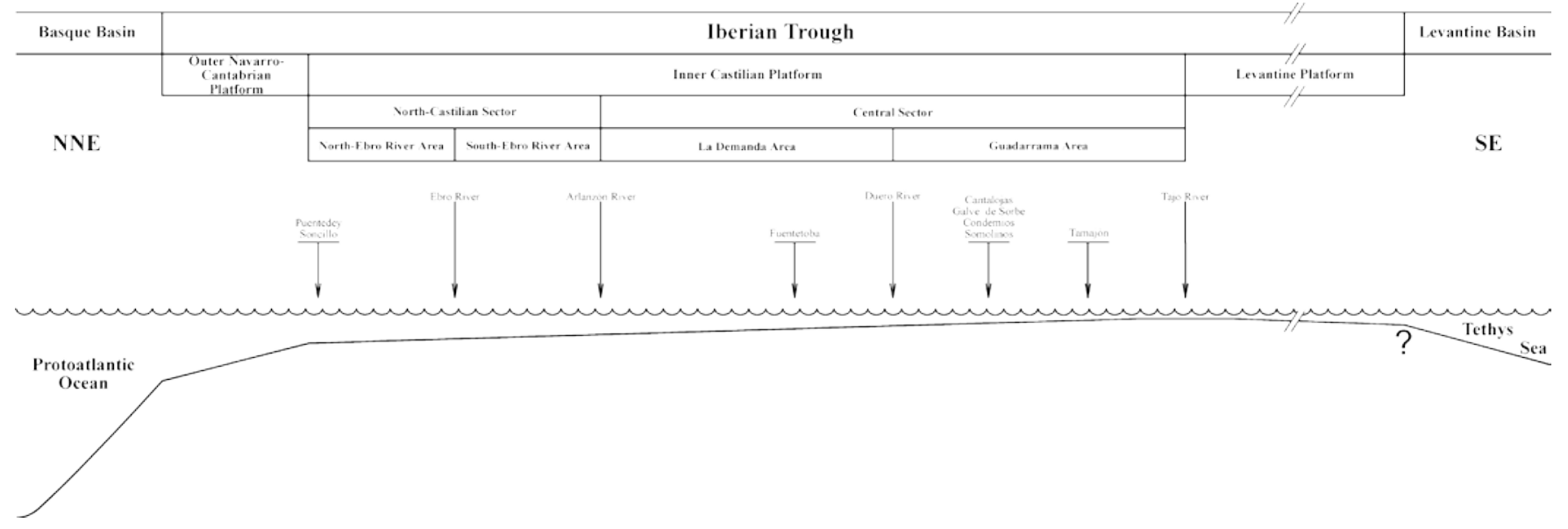

Fig. 2. Divisions followed in the Iberian Trough, with indication of the approximate location of the studied outcrops and the geographic boundaries between their different palaeogeographic areas.

established the zone TV, also named of Fagesia spp., within the Outer Navarro-Cantabrian Platform, on the basis of the common occurrence of the members of this genus. This new interval attributed to Fagesia seems more correct, and in accordance with the rest of the Spanish records of this genus obtained by other authors.

The AG and MH collections contain several ammonites, collected from the Choffaticeras (Leoniceras) luciae subzone and the base of the Mammites nodosoides zone of the Guadarrama Area, that were classified by Meléndez-Hevia (1984) as F. cf. tehevensis [sic] (Peron, 1896). Among these specimens, the ones not illustrated can easily be assigned to this

\begin{tabular}{|c|c|c|c|c|c|}
\hline \multirow[t]{2}{*}{ Substage } & \multirow{2}{*}{$\begin{array}{l}\text { Standard ammonite zonation. } \\
\text { Based on Kennedy (1984), } \\
\text { Tröger \& Kennedy (1996), } \\
\text { Bengston (1996) and } \\
\text { Gradstein et al. (2004). }\end{array}$} & \multirow{2}{*}{\multicolumn{2}{|c|}{$\begin{array}{l}\text { North of Spain. Wiedmann } \\
\& \text { Kauffman (1978) and } \\
\text { Wiedmann (1979). }\end{array}$}} & \multicolumn{2}{|c|}{$\begin{array}{c}\text { Iberian Trough, Spain. } \\
\text { Barroso-Barcenilla, Goy \& } \\
\text { Segura (manuscript in } \\
\text { review). }\end{array}$} \\
\hline & & & & Zones & Subzones \\
\hline \multirow{4}{*}{ 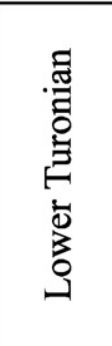 } & \multirow{2}{*}{$\begin{array}{l}\text { Mammites } \\
\text { nodosoides }\end{array}$} & $\left|\begin{array}{|c|}\text { Wrightoceras munieri } \\
+ \text {-Spathitoides sulcatus }\end{array}\right|$ & TV & \multirow{2}{*}{$\begin{array}{c}\text { Mammites } \\
\text { nodosoides }\end{array}$} & $\begin{array}{l}\text { Wrightoceras } \\
\text { munieri }\end{array}$ \\
\hline & & \multirow[b]{2}{*}{$\begin{array}{l}\text { Ingridella malladae } \\
+ \\
\text { Schindewolfites spp. }\end{array}$} & \multirow[b]{2}{*}{ T IV } & & $\begin{array}{l}\text { Mammites } \\
\text { nodosoides }\end{array}$ \\
\hline & \multirow{2}{*}{ Watinoceras devonense } & & & $\mid \begin{array}{c}\text { Spathites } \\
\text { (Ingridella) } \\
\text { malladae }\end{array}$ & \begin{tabular}{|c}
$\begin{array}{c}\text { Choffaticeras } \\
\text { (Leoniceras) } \\
\text { luciae }\end{array}$ \\
$\begin{array}{c}\text { Spathites } \\
\text { (Ingridella) } \\
\text { malladae }\end{array}$ \\
\end{tabular} \\
\hline & & \begin{tabular}{|c|} 
Leoniceras discoidale \\
+ \\
Paramammites? \\
saenzi
\end{tabular} & T III & \multicolumn{2}{|c|}{$\begin{array}{c}\text { Choffaticeras } \\
\text { (Choffaticeras) } \\
\text { quaasi }\end{array}$} \\
\hline \multirow{7}{*}{ 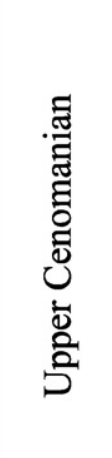 } & $\begin{array}{l}\text { Neocardioceras } \\
\quad \text { juddii }\end{array}$ & $\begin{array}{c}\text { Fallotites } \\
\text { subconciliatus }\end{array}$ & T II & \multicolumn{2}{|c|}{$\begin{array}{c}\text { Spathites } \\
\text { (Jeanrogericeras) } \\
\text { subconciliatus }\end{array}$} \\
\hline & \multirow{2}{*}{$\begin{array}{l}\text { Metoicoceras } \\
\text { gesliniamum }\end{array}$} & Vascoceras gamai & T I & \multirow{2}{*}{$\begin{array}{l}\text { Metoicoceras } \\
\text { geslinianum }\end{array}$} & $\begin{array}{c}\text { Vascoceras } \\
\text { gamai }\end{array}$ \\
\hline & & $\begin{array}{l}\text { Metoicoceras } \\
\text { geslinianum }\end{array}$ & $\mathrm{C}$ VII & & $\begin{array}{c}\text { Metoicoceras } \\
\text { gesliniamum }\end{array}$ \\
\hline & & $\begin{array}{c}\text { Metoicoceras } \\
\text { muelleri }\end{array}$ & $\mathrm{C}$ VI & & $\begin{array}{c}\text { Metoicoceras } \\
\text { mosbyense }\end{array}$ \\
\hline & Calycoceras & $\begin{array}{l}\text { Calycoceras (Lotzeites) } \\
\text { cotzei }+ \\
\text { Neolobitery yibryeanus }\end{array}$ & $\mathrm{c} \mathrm{V}$ & vibrayeamus & $\begin{array}{l}\text { Neolobites } \\
\text { vibrayeamus }\end{array}$ \\
\hline & $\begin{array}{c}\text { (Proeucalycoceras) } \\
\text { guerangeri }\end{array}$ & Eucalycoceras & C & ceras & $\begin{array}{c}\text { Calycoceras } \\
\text { (Calycoceras) } \\
\text { naviculare }\end{array}$ \\
\hline & & & IV & rowei & $\begin{array}{l}\text { Eucalycoceras } \\
\text { rowei }\end{array}$ \\
\hline
\end{tabular}

Fig. 3. Possible correlation of the biostratigraphic zonation followed in this work and other Spanish as well as the standard scales. species of Peron, but the one shown in the illustration cannotbe attributed to F. tevesthensis. This ammonite has subtriangular whorl section, narrow umbilici and marked ribs, and must therefore be remitted to F. mortzestus sp. nov. (see below, Section 4.4). The JW collection also includes a doubtful member of F.tevesthensis collected in the middle Turonian of the North-Ebro Area.

The AG collection has specimens of F. rudra (Stoliczka, 1865) obtained from the lower part of the Mammites nodosoides zone of the Guadarrama Area. In the JW, collection there is an ammonite assigned to F. rudra from the North-Ebro Area.

The AG and $\mathrm{MH}$ collections hold some specimens of F.superstes (Kossmat, 1897) collected from the M. nodosoides zone of the Guadarrama Area. The JW collection contains two ammonites located in the Outer Navarro-Cantabrian Platform and the North-Ebro Area, and classified as F. superstes and F. cf. superstes by Wiedmann, which were not cited by this author.

This collection also has two ammonites, attributed by Wiedmann $(1960 a, 1964,1979)$ to F. bomba (Eck, 1909) and F. cf. bomba, found in the Outer Navarro-Cantabrian Platform.

\subsection{Neoptychites Kossmat, 1895}

The JW collection holds some specimens of $N$. cephalotus (Courtiller, 1860) and $N$. cf. cephalotus, obtained mainly from the middle Turonian zone T VI of the North-Ebro Area.

The same collection also has an ammonite from the zone $T$ VI of the North-Ebro Area, which was classified as $N$. telingaeformis Solger, 1904, by Wiedmann, but was not previously cited.

\section{New data of Fagesia and Neoptychites} (Vascoceratidae) in the Iberian Trough

In this section we present a systematic description of new records of the family Vascoceratidae Douvillé, 1912, from the Iberian Trough, obtained during field works carried out by the 
first author. Wealso describe previously unpublished members of the genera Fagesia Pervinquière, 1907, and Neoptychites Kossmat, 1895, identified in the AG and MH collections.

\subsection{Acronyms and abbreviations}

Tomake clear some taxonomic comments or to indicate the location of several type specimens, the following abbreviations are used throughout the text:

- British Museum (Natural History) (BMNH), London, UK;

- Château de Saumur (CS), France;

- Universität Tübingen (UT), Germany;

- International Code of Zoological Nomenclature (ICZN);

- Musée national d'Histoire Naturelle (MNHN), Paris, France;

- Universidad Complutense de Madrid (UCM), Spain;

- Université Pierre-et-Marie-Curie (UPMC), Paris, France.

\subsection{Terminology}

The terminology used to describe the different specimens studied is based on the glossary of morphological terms applicable to post-Triassic nautiloids and ammonoids proposed by Barroso-Barcenilla (2008).

\subsection{Dimensions and location of specimens}

Measurements were made with an adjustable caliper, and are given in tenths of millimetre and as percentages of the diameter shell. The dimensions used in the analysis are defined as follows:

- diameter of the shell (D), maximum distance between two diametrically opposite ventral extremes, measured perpendicularly to the coiling axis;

- whorl height $(\mathrm{H})$, maximum distance between the ventral extremeand the most distanced point of the dorsal wall, taken parallelly to the plane of bilateral symmetry;

- whorl breadth (B), maximum distance between both flanks, measured perpendicularly to the coiling axis (tubercles and ribs have not been taken into account);

- umbilical width $(\mathrm{U})$, maximum distance, taken perpendicularly to the coiling axis, separating two diametrically opposite umbilical margins of the same whorl.

All the specimens presented here are held in the Departamento de Paleontología of the UCM.

\subsection{Systematic palaeontology}

VASCOCERATIDAE Douvillé, 1912.

[NEOPTYCHITINAE Collignon, 1965, p. 70].

Diagnosis, discussion and occurrence: a detailed analysis of the main characteristics of this family is presented by Barroso-Barcenilla and Goy (manuscript in review).

Fagesia Pervinquière, 1907
[Plesiovascoceras Spath, 1925, p. 198, type species by original designation Ammonites catinus Mantell, 1822].

Type species: Olcostephanus superstes Kossmat, 1897, by original designation.

Diagnosis: globose cadicones with arched ventral region, wide and deep umbilici and strong and blunt umbilical tubercles. From each of these tubercles two or three rounded ribs grow and cross the ventral region. Most of its members have a coronate section. Ornamentation usually remains unchanged until advanced ontogenetic stages. During growth some species can lose tubercles and ribs, reaching maturity with a totally smooth shell or with some occasional constrictions. The suture lines are more complex than in most vascoceratids, with many deep and narrow minor elements. Each suture line presents three or four narrow, well-developed and bifurcate lobes and marked saddles per flank, the first two of them being usually trifid and asymmetric.

Discussion: after studying some features of the suture lines of Olcostephanus superstes Kossmat, 1897, and comparing them with those of other members belonging to its group, Pervinquière (1907) established the genus Fagesia and designated this species of Kossmat as type. Eck (1909) stated that the most particular feature of $F$. superstes lies in its suture lines, more exactly in their deep incisions. Spath (1925) established the genus Plesiovascoceras, and included in it several evolute species with strong umbilical tubercles and ribs that disappear as they approach to the ventral region. Later on many authors, like Barber (1957), preferred to maintain the generic status of Plesiovascoceras, although they pointed out the important morphologic similarities with Fagesia. Wiedmann $(1960 a, 1964,1979)$ attributed to Plesiovascoceras its own temporal distribution, slightly earlier than that which he assigned to Fagesia. Bengtson $(1979,1983)$ indicated that the type of F. multiplex Brito, 1971, is an Albian ammonite, probably a large member of the genus Douvilleiceras de Grossouvre, 1894. Wright and Kennedy (1981) remarked that F. superstes hardly differs from A. catinus, which has a slightly more involute coiling and an apparently bifid first lateral lobe. These authors stated that the characteristics indicated do not justify a generic division. After the work of Wright and Kennedy (1981)mostauthors, likeChancellor(1982), Kennedy et al. (1987), Chancellor et al. (1994) and Kaesler in Wright (1996), opted to include Plesiovascoceras within Fagesia as a synonym.

In recent years, several authors have studied the species that can be attributed to Fagesia. Kennedy and Wright (1979) assigned to this genus F.superstes, which shows the diagnostic features of the same group, F. peroni Pervinquière, 1907, F. rudra (Stoliczka, 1865), F. bomba (Eck, 1909), F. boucheroni (Coquand, 1859), F. simplex Barber, 1957, F. catinus, F. involute Barber, 1957, F.pachydiscoides Spath, 1925, and, as a nomen dubium, F.tehevesthensis (Peron, 1897). Chancellor(1982) statedthat F.haarmanniBöse, 1920, should maintain its specifi status, as he considered that this species is not a synonym of F.catinus. He also doubted of the specifi status of $F$. pachydiscoides, and preferred to maintain F.californica Anderson, 1931, as a species. Kennedy et al. 
(1987) regarded as conspecifi with F.catinus all forms of the genus identifi by Renz (1982), including F. levis, and modifi the number of species of the group accepted by Kennedy and Wright (1979). They considered F. tevesthensis and F.pachydiscoides as possible synonyms of F. superstes and F. catinus, respectively. The same authors accepted the specifi status of F. lenticularis Freund and Raab, 1969, and indicated that, as pointed out by Barber (1957), the lack of umbilical tubercles in F. rudra, F. bomba and F. involuta, as well as in F. pervinquieri Böse, 1920, could be reason enough for assigning these species to the genus Vascoceras Choffat, 1898. Zaborski (1987) accepted the specifi validity of F. levis and F.zanelli Etayo-Serna, 1979, and carried out an interesting analysis of the main features which differentiates the several taxa of this genus from each other. He emphasised that $F$. superstes shows ribs and strong umbilical tubercles that remain through ontogeny. F. tevesthensis and F. boucheroni lose ribs on early ontogenetic stages, as also happens with F. peroni, which has robust umbilical tubercles. F. zanelli achieves a stronger ribbing during growth. F. bomba and $F$. involuta develop involute coilings and F. simplex shows simple suture lines, but these three species soon lose their ribs. F. lenticularis is characterised by an eccentric and strange coiling, F. rudra almost lacks umbilical tubercles, and F. pachydiscoides has a quite compressed whorl section. Finally, the same author indicated that the umbilical tubercles of $F$. catinus become more robust during ontogeny, being maintained until adultage, and that the globose shell of $F$.levis presents slightly evolute coiling and relatively spacious ribbing. Chancellor et al. (1994) maintained the specifi status of $F$.tevesthensis, and considered F. bomba as a mere synonym of F.superstes, whose specimens are not distinguishable from the globose members of this taxon. They indicated the differing features among F.haarmanni, F.californica and F. shastensis Anderson, 1931, and accepted the inclusion of F. pervinquieri and F. simplex within Vascoceras, due to the simplicity of their suture lines. The same authors remarked that the almost unknown species F. lenticularis has numerous similarities with $F$. rudra. They added that the strange asymmetric coiling of $F$. lenticularis could have been caused by post mortem deformations, and suggested that F. multiplex seems to be an eroded puzosid. Finally, Chancellor et al. (1994) identifi the strange species F. fleuryi Pervinquière, 1907, although they indicated that it should be considered a nomen dubium and assigned to other genera of the Vascoceratidae Douvillé, 1912, due to its lack of tubercles.

Concerning the phylogeny of Fagesia, Wright and Kennedy (1981) stated that the sharp aspect of the ventrolateral margins of some specimens of this group could be caused by the possible proximity of the genus of Pervinquière to the subgenus Spathites (Jeanrogericeras) Wiedmann, 1960a. However, they added that the representatives of $S$. (Jeanrogericeras) have a double line of ventrolateral tubercles during the first ontogenetic stages, which members of Fagesia lack.

Occurrence: the genus Fagesia occurs from the upper Cenomanian to the middle Turonian of the UK, France, Spain, Portugal, North Africa, Nigeria, Cameroon, Gabon,
Madagascar, the Middle East, India, the USA, Mexico, Colombia, Venezuela, Brazil and Japan. This genus is commonly considered a typical Turonian group, although Hook and Cobban (1981) and Cobban et al. (1989) seemingly collected some specimens of Fagesia in the upper Cenomanian Neocardioceras juddii zone of the USA. The palaeobiostratigraphic distribution of this genus was analysed by Matsumoto (1973) and Matsumoto and Muramoto (1978), among others. In this regard, Wright and Kennedy (1981) pointed out that Fagesia is one of the most widespread vascoceratids.

In the Iberian Trough, this group has been obtained in both the Outer Navarro-Cantabrian Platform and the Inner Castilian Platform. In spite of the fact that a single specimen of Fagesia has been found at the top of the Spathites (Jeanrogericeras) subconciliatus zone, a continuous record of this genus have been obtained from the upper part of the Choffaticeras (Leoniceras) luciae subzone to, at least, the top of the Mammites nodosoides zone.

Fagesia catinus (Mantell, 1822)

Fig. 4(1-3).

1822. Ammonites catinus - Mantell, p. 198, PI. 22, Fig. 10 [non Fig. 5 (= error)].

1920. Fagesia haarmanni-Böse, p. 211, PI. 14, Figs. 1, 2; PI. 15, Fig. 2.

1923. Vascoceras thomi-Reeside, p. 29, PI. 11, Figs. 1, 2; Pl. 12, Figs. 1, 2; PI. 13, Figs. 1, 2; PI. 14, Figs. 1, 2; PI. 15, Figs. 1-7; PI. 16, Figs. 1-6.

1923. Vascocerasmoultoni-Reeside, p. 30, PI. 17, Figs. 1, 2; PI. 18, Figs. 1, 2.

1923. Vascoceras stantoni-Reeside, p. 30, Pl. 19, Figs. 1, 2; PI. 20, Figs. 1-3; PI. 21, Figs. 1-3.

1925. Plesiovascoceras catinum (Mantell) - Spath, p. 198. 1925. Fagesia nov. sp. - Spath, p. 198.

? 1931. Fagesia californica-Anderson, p. 123, PI. 15, Fig. 1; PI. 16, Figs. 1, 2; Pl. 17, Fig. 1, Text-Fig. 1 a.

? 1931. Fagesia shastensis-Anderson, p. 124, PI. 16, Fig. 3, Text-Fig. 1b.

1940. Vascoceras (Pachyvascoceras) bernonense - Faraud, p. 15, PI. 7, Fig. 1; Pl. 9, Fig. 3; PI. 10.

1954. Fagesia haarmanni Böse - Kummel and Decker, p. 313 , Text-Fig. 3.

? 1958. Fagesia californica Anderson-Anderson, p. 248, PI. 39, Figs. 1, 2.

? 1958. Vascoceras shastense (Anderson) - Anderson, p. 248.

? 1959. Plesiovascoceras californicum (Anderson) - Matsumoto, p. 102, PI. 36, Figs. 1a-c, Text-Fig. 54a, b.

1963a. Fagesia haarmanni Böse - Powell, p. 320, Pl. 33, Fig. 2; Pl. 34, Figs. 1-5, Text-Fig. 2h-k.

1969. Fagesia superstes (Kossmat) var. tunisiensis Pervinquière - Thomel, p. 116, PI. d, Figs. 1, 2; Pl. e, Figs. $1,2$.

? 1972. Fagesia sp. -Cobban and Scott, p. 88, PI. 34, Figs. 1, 2; PI. 38, Fig. 4.

1978. Plesiovascoceras catinum (Mantell) - Kennedy and Hancock, p. V19. 


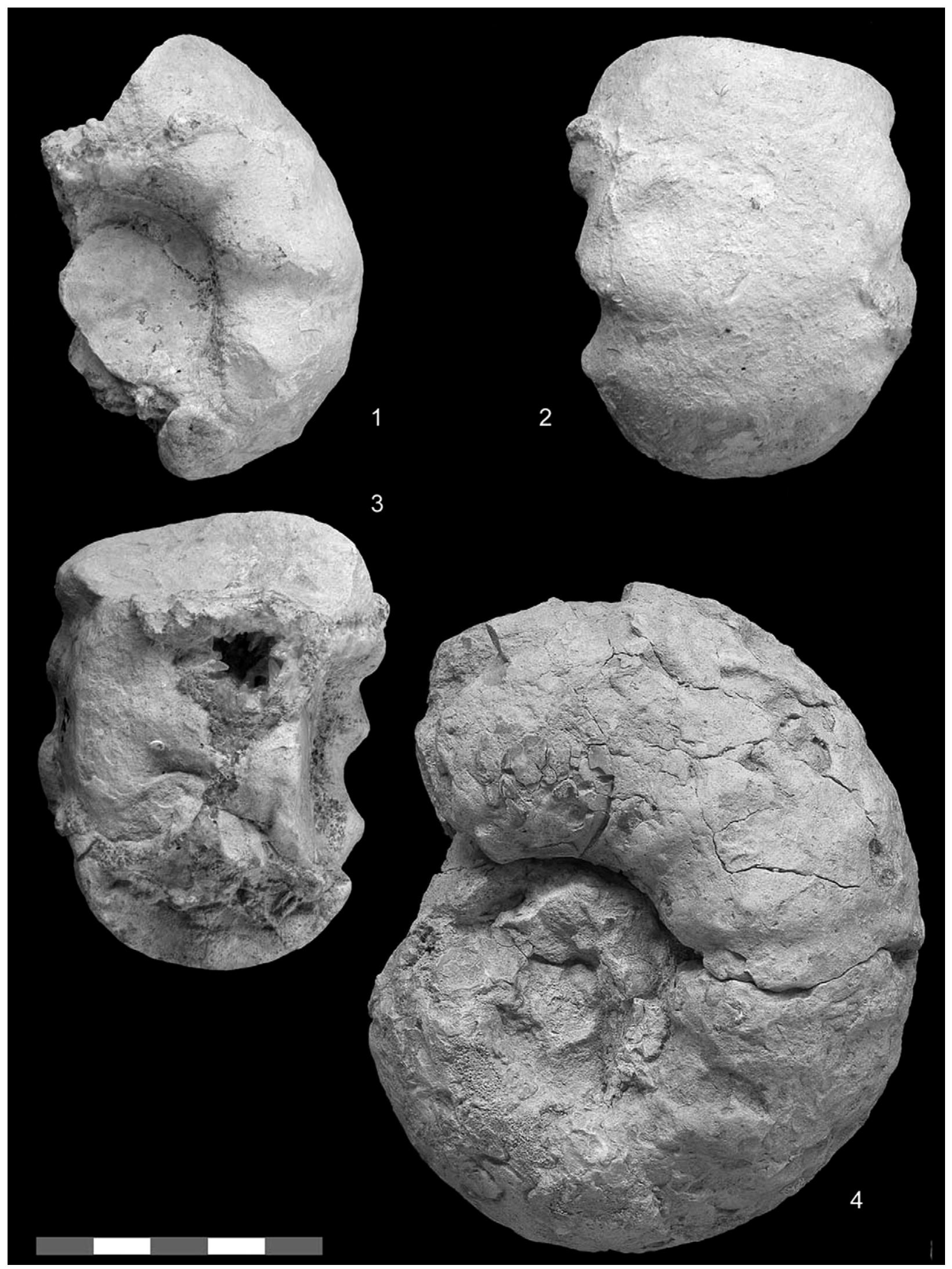

Fig. 4. 1, 2, 3. Fagesia catinus (Mantell, 1822), specimen FT-R-739, from an unknown lower Turonian level of Fuentetoba. 1. Lateral view. 2. Ventral view. 3. Apertural view. 4. Fagesia tevesthensis (Peron, 1896), specimen TA-S-585, from the Choffaticeras (Leoniceras) luciae subzone of Tamajón, lateral view. Bar scale $=5 \mathrm{~cm}$. 
1981. Fagesia catinus (Mantell) - Wright and Kennedy, p. 88, PI. 26, Fig. 2, Text-Figs. 31-36.

1981. Fagesia or Vascoceras sp. - Hook and Cobban, PI. 2 , Figs. 1, 2, 5 .

1986. Fagesia catinus (Mantell) - Kennedy, PI. 12, Figs. 1,

$2,8,9$.

1987. Fagesia catinus (Mantell) - Kennedy et al., p. 51, PI. 7, Figs. 1-11,?12, 13; PI. 8, Figs. 1-4, 6-9; Text-Figs. 2j, k, $\mathrm{m}, \mathrm{n}, 10$.

1989. Fagesia catinus (Mantell) - Cobban et al., p. 50, Figs. 50, 92I-k, 96s, t.

1989. Fagesia catinus (Mantell) - Kennedy et al., p. 84.

1991. Fagesia catinus (Mantell)-Kennedyand Simmons, p. $141, \mathrm{Pl}$. 4c-e.

1992. Fagesia catinus catinus (Mantell) - Thomel, p. 229, PI. 84, Fig. 1; PI. 85; PI. 86, Fig. 1; PI. 89, Fig. 3; PI. 90, Figs. 1, 2; PI.?93; Pl.?94, Figs. 1, 2.

1994. Fagesia catinus (Mantell) - Kennedy, p. 260, PI. 7, Figs. 6-8.

1994. Fagesia catinus (Mantell) - Kassab, p. 121, Fig. 5(8).

1996. Fagesia catinus (Mantell)-Kaesler inWright, p. 176,

Text-Fig. 136/1d, e.

2001. Fagesia catinus (Mantell) - Callapez and Ferreira, p. 86, PI. 13, Figs. 5, 6, Text-Figs. 23.5-6.

2006. Fagesia catinus (Mantell) - Barroso-Barcenilla, p. 255, Pl. 35, Figs. g, h; Pl. 36, Fig. a.

Type: the holotype by monotypy is specimen C3379 of the BMNH, original of Mantell (1822: Pl. 22, Fig. 10) and collected from the lower Turonian of Lewes, UK.

Material and dimensions:

\begin{tabular}{llrrr}
\hline & D & \multicolumn{1}{c}{ H (\%) } & \multicolumn{1}{c}{ B (\%) } & \multicolumn{1}{c}{$U(\%)$} \\
\hline FT-R-739 & 800 & $246(31)$ & $565(71)$ & $322(40)$ \\
PU-R-247 & 498 & rv172(35) & rv480(96) & rv150(30) \\
\hline
\end{tabular}

Description: moderately involute or evolute ammonites with depressed half moon-shaped or reniform whorl section, broad venter and deep crateriform umbilici with flat and sloping walls. The smallest specimen bears 8-12 umbilical tubercles per whorl, with one or two prorsiradiate ribs arising from each of them. Likewise, some intercalated ribs can be observed in it. During ontogeny, the whorls become more evolute, umbilical width increases and ornamentation disappears, although the umbilical tubercles persist. Likewise, the ribs, which range 2030 per spire, decline until they almost disappear.

Discussion: Wright and Kennedy (1981) carried out an interesting and detailed revision of F.catinus (Mantell, 1822). They refigured its holotype and some specimens of Reeside (1923) and Spath (1925), and included F. haarmanni Böse, 1920, Vascoceras mohovanense Böse, 1920, V. thomi Reeside, 1923, V.moultoni Reeside, 1923, V. stantoni Reeside, 1923, F. californica Anderson, 1931, F. shastensis Anderson, 1931, and V.(Pachyvascoceras) bernonense Faraud, 1940, within the synonymy of $F$. catinus. The same authors maintained F. pachydiscoides Spath, 1925, as a separate species, on the basis of its narrower, higher and more rounded whorl section. Finally, Wright and Kennedy (1981) suggested the possible existence of sexual dimorphism in F. catinus. On the contrary, Chancellor (1982) considered that F. haarmanni presents a more involute and depressed shell with a flatter and broader venter than F. catinus, and observed a morphological convergence between the latter species and F.pachydiscoides. Kennedy et al. (1987), as well as Kennedy et al. (1989), Kennedy and Simmons (1991) and Kennedy (1994), considered F. haarmanni, F. pachydiscoides and the different taxa attributed to this genus by Renz (1982), among them F. levis, F. aff. superstes, F. cf. tevesthensis, F. aff. F. haarmanni and? F.sp., as synonyms of F.catinus. Zaborski (1987), on the other hand, preferred to accept the specific status of F.levis. Kennedy (1994) agreed with the remarks made by Kennedy etal. (1987) and added that the original description of $V$. (P.) bernonense is based on a specimen of F. catinus in an intermediate ontogenetic stage. Thomel (1992) found transitional specimens between F.catinus and F.pachydiscoides, and relegated the second taxa to the subspecific status, proposing his new taxon F. catinus niciensis. Santamaría-Zabala (1991, $1995)$ found that $F$. catinus has a slightly more involute coiling and a wider and less rounded whorl section than F. pachydiscoides, maintaining them as different species.

In fact, the types of F. haarmanni, V. thomi, V. moultoni, $V$. stantoni, F. nov. sp. of Spath (1925) and V. (P.) bernonense are morphologically very close to the holotype of F. catinus, and, therefore, these taxa seem to be mere synonyms of this species of Mantell. F. californica and F. shastensis could represent the more compressed and closer to F.pachydiscoides morphological extreme of $F$. catinus. Consequently, F. californica and F. shastensis, as well as the specimen of Thomel (1992: PI. 93; PI. 94, Figs. 1, 2), might be transitional forms between the species F. pachydiscoides and F. catinus. $V$. mohovanense exhibits coarse ornamentation, with marked ribs, and relatively depressed whorl section, and F. levis has spires, whose width is more than three times its height. These features differentiate $V$. mohovanense and $F$. levis from F. catinus, and thus we consider it reasonable to keep their specific separation. On the other hand, the features of the specimens of F. superstes var. tunisiensis Pervinquière, 1907, of Thomel (1969), with great umbilical width and virtual lack of ribs, seem to coincide with those of the members of F. catinus, as observed by Wright and Kennedy (1981), among other authors. Finally, immature specimens of F. sp. of Cobban and Scott (1972) may also possibly be assigned to F.catinus, but their precise taxonomic classification cannot be established since they are in early ontogenetic stages.

F. catinus, considered the type species of Plesiovascoceras Spath, 1925, possesses a depressed whorl section, making it difficult to distinguish from F. superstes. Nevertheless, the former species reaches a more evolute coiling than the latter one and loses ribbing in the early growth stages. As already emphasised by Wright and Kennedy (1981), F. catinus and other species of the genus differ from the most globose members of Vascoceras Choffat, 1898, such as V. harttiforme Choffat, 1898, and V.douvillei Choffat, 1898, in the simpler and shorter sutural elements, more involute coilings and less persistent or absent umbilical tubercles of the latters. 
Occurrence: previously identified from the upper Cenomanian to the lower Turonian of the UK, Mexico, USA, Oman, France, Egypt and Portugal. F. catinus is the stratigraphically lowest species of the genus. Despite being characteristic of the lower Turonian, it was apparently identified by Cobban et al. (1989) in the upper Cenomanian Neocardioceras juddii zone of New Mexico, USA. According to Kennedy (1994), F. catinus is a typical boreal species. The two Spanish specimens presented herein have been collected in the Iberian Trough, specifically in levels of the upper Cenomanian Spathites (Jeanrogericeras) subconciliatus zone of the North-Ebro Area that were deposited during the Cenomanian-Turonian transition, and of the lower Turonian of the La Demanda Area.

Fagesia tevesthensis (Peron, 1896)

Figs. 4(4) and Fig. 5(1).

? 1860. Ammonites alphonsi-Coquand, p. 966.

1896. Mammites? tevesthensis - Peron, p. 23, PI. 7, Figs. $2,3$. cf. 1898. Ammonites cf. tevesthensis (Peron) - Choffat,

p. 70 , Pl. 10, Fig. 5.

? 1904. Ammonites kotoi - Yabe, p. 26, Pl. 6, Figs. 3, 4.

1907. Fagesia thevestensis (Peron)-Pervinquière, p. 325,

PI. 20, Figs. 5, 6, Text-Figs. 123, 124.

cf. 1914. Fagesia sp. ind. cf. F.thevesthensis (Peron) - Eck, p. 199.

1939. Fagesia thevesthensis (Peron)-Basse, p. 49.

? 1960a. Fagesia? thevestensis (Peron) - Wiedmann, p. 719.

? 1964. Fagesia? thevestensis (Peron) - Wiedmann, p. 114.

1969. Fagesia thevesthensis (Peron) - Freund and Raab,

p. 35 , Text-Fig. $7 \mathrm{~g}$.

? 1969. Fagesia sp. -Freund and Raab, p. 42, PI. 7, Fig. 4, Text-Fig. 9d, e.

1973. Fagesia thevesthensis (Peron) - Matsumoto, p. 32,

PI. 8, Fig. 2a-c, Text-Fig.? 2.

? 1979. Fagesia? thevestensis (Peron) - Wiedmann, p. 189.

non 1982. Fagesia cf. thevestensis (Peron) - Renz, p. 79,

PI. 22, Fig. 15a, b.

1984. Fagesia cf. thevestensis (Peron) - Meléndez-Hevia,

p. 92 [only].

1994. Fagesiatevesthensis(Peron)-Kennedy, p. 261, PI. 7,

Figs. 1-4; PI. 9, Figs. 6, 7.

1994. Fagesia tevesthensis (Peron) - Chancellor et al., p. 62,

PI. 15, Figs. 1-3, 10, 11.

2001. Fagesia tevesthensis (Peron) - Callapez and Ferreira,

p. 85, Pl. 13, Figs. 1, 4, 9, 10, Text-Figs. 23.7, 23.9-10.

2006. Fagesia tevesthensis (Peron) - Barroso-Barcenilla, p. 258 , PI. 36, Figs. b, c.

Type: the holotype by monotypy is the specimen of Peron

(1896: p. 23, PI. 7, Figs. 2, 3), from Tebessa, Algeria, and currently held with the number $\mathrm{J} 043202$ in the MNHN, after being kept in the UPMC.

Material and dimensions:

\begin{tabular}{lrlll}
\hline & $\mathrm{D}$ & $\mathrm{H}(\%)$ & $\mathrm{B}(\%)$ & $\mathrm{U}(\%)$ \\
\hline TA-S-577 & 1150 & $398(35)$ & $533(46)$ & $475(41)$ \\
& 696 & $215(31)$ & $378(54)$ & $259(37)$ \\
TA-S-585 & 1213 & $524(43)$ & $567(47)$ & $414(34)$ \\
\hline
\end{tabular}

Description: medium-sized and slightly evoluteammonites, with depressed subreniform whorl section, rounded venter and flanks and relatively broad umbilici. Each whorl bears about 15 umbilical tubercles per flank that give rise to groups of three coarse and slightly prorsiradiate main ribs. Intercalated ribs arise among them. During ontogeny, the ribbing and the umbilical tubercles weaken.

Discussion: Peron (1897) already pointed out the difficulty of differentiating between his new species Ammonites tevesthensis and Olcostephanus superstes Kossmat, 1897, since their respective appearances are relatively close. Pervinquière (1907: Pl. 20, Fig. 5) noticed the existence of specimens with intermediate features between these two species. He also indicated that Ammonites alphonsii Coquand, 1860, represents an intermediate form between F. tevesthensis and F. superstes. For this reason the same author included the latter taxon in the synonymy of the former one, as did other subsequent authors such as Basse (1939). Likewise, Pervinquière (1907) and other authors, like Basse (1939), Matsumoto (1973), Kennedy (1994) and Chancellor et al. (1994), maintained that Ammonites kotoi Yabe, 1904, might be a conspecific form of $F$. tevesthensis. Kennedy et al. (1987) suggested that $F$. tevesthensis could be a synonym of $F$. superstes, and attributed to F.catinus the specimen classified by Renz (1982) as F. cf. thevestensis. Chancellor et al. (1994) indicated that the location of the original specimen of Coquand, that was never illustrated, is unknown, and therefore regarded A. alphonsii as a nomen dubium.

Regarding the separation of F. tevesthensis and F. superstes, it should be observed that the first species shows a more compressed whorl section and a more dense ribbing than the second one. Likewise, F.superstes has globose morphology and proportionately more reduced and deeper umbilici. Both features make it easy to distinguish between these two taxa. In the same way it can be added that, although the stratigraphical distributions of both species are relatively close and the reduced number of specimens obtained is not high enough to reach definitive conclusions, the records of F. tevesthensis in the Iberian Trough are lower than those of F. superstes. Taking into account the observations on morphology and distribution indicated above, we recommend maintaining the specific division of these two taxa. On the other hand, although the type of $A$. kotoi is an incomplete specimen in poor state of preservation, the appearance and dimensions of it seem to coincide with those of the members of F. tevesthensis.

The small specimen classified as Fagesia sp. by Freund and Raab (1969) also has the typical appearance of the representatives of $F$. tevesthensis, which is why it should probably be assigned to this species. On the contrary, the ammonite classified as F. cf. thevestensis by Renz (1982) presents a whorl section that is too depressed to be a member of the species of Peron.

Occurrence: F.tevesthensis occurs in the lower Turonian of Algeria, Portugal, Tunisia, Egypt, France, Israel, Japan and Spain. This species was assigned by Chancellor etal. (1994) to the Thomasites rollandizone of Tunisia, which is equivalent to the upper part of the Watinoceras devonense standard zone. In 


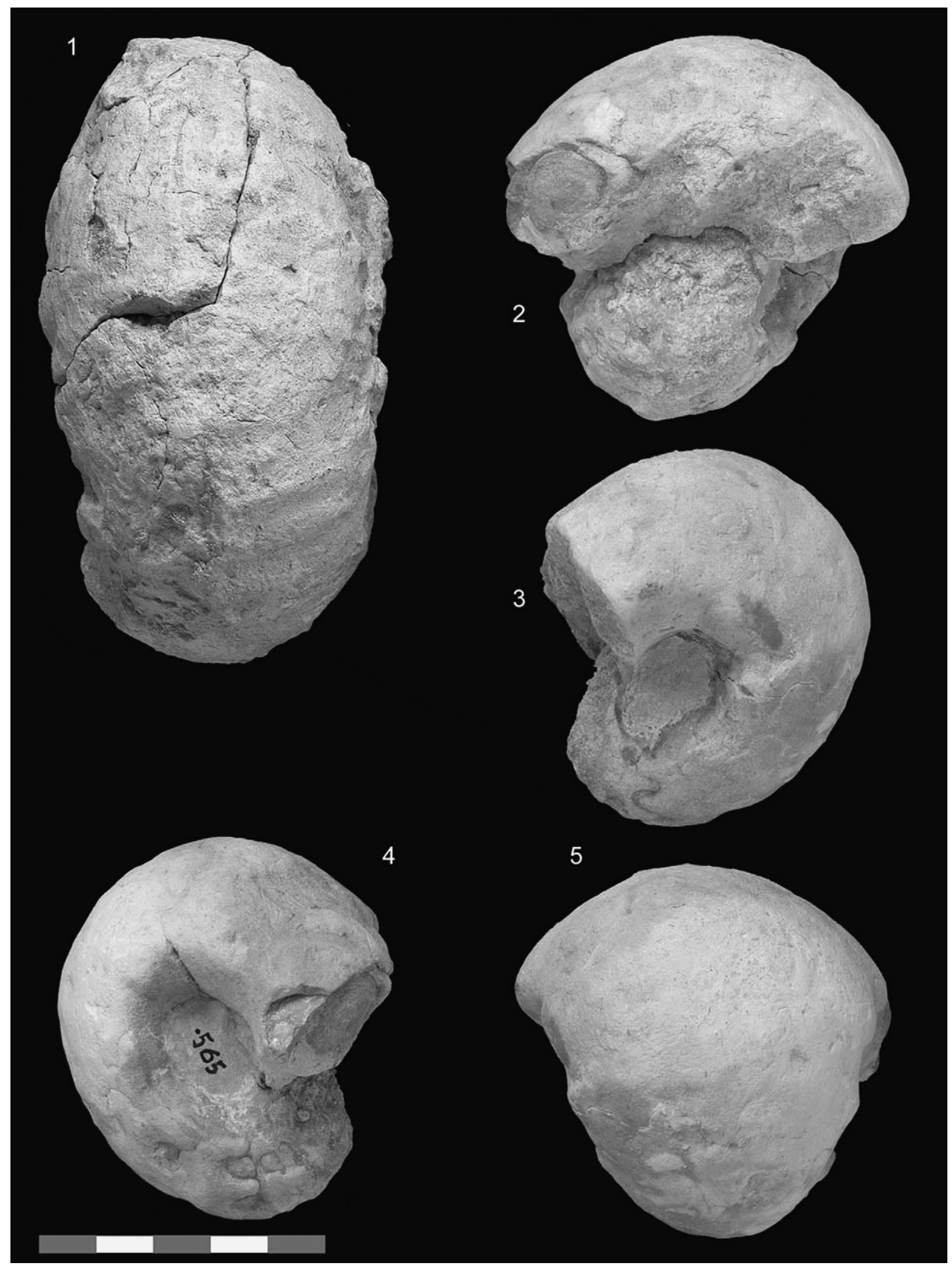

Fig. 5. 1. Fagesia tevesthensis (Peron, 1896), specimen TA-S-585, from the Choffaticeras (Leoniceras) luciae subzone of Tamajón, ventral view. 2, 3, 4, 5. Fagesia rudra (Stoliczka, 1865), specimen TA-S-565, from the Mammites nodosoides subzone of Tamajón. 2. Apertural view. 3 and 4. Lateral views. 5. Ventral view. Bar scale $=5 \mathrm{~cm}$. 


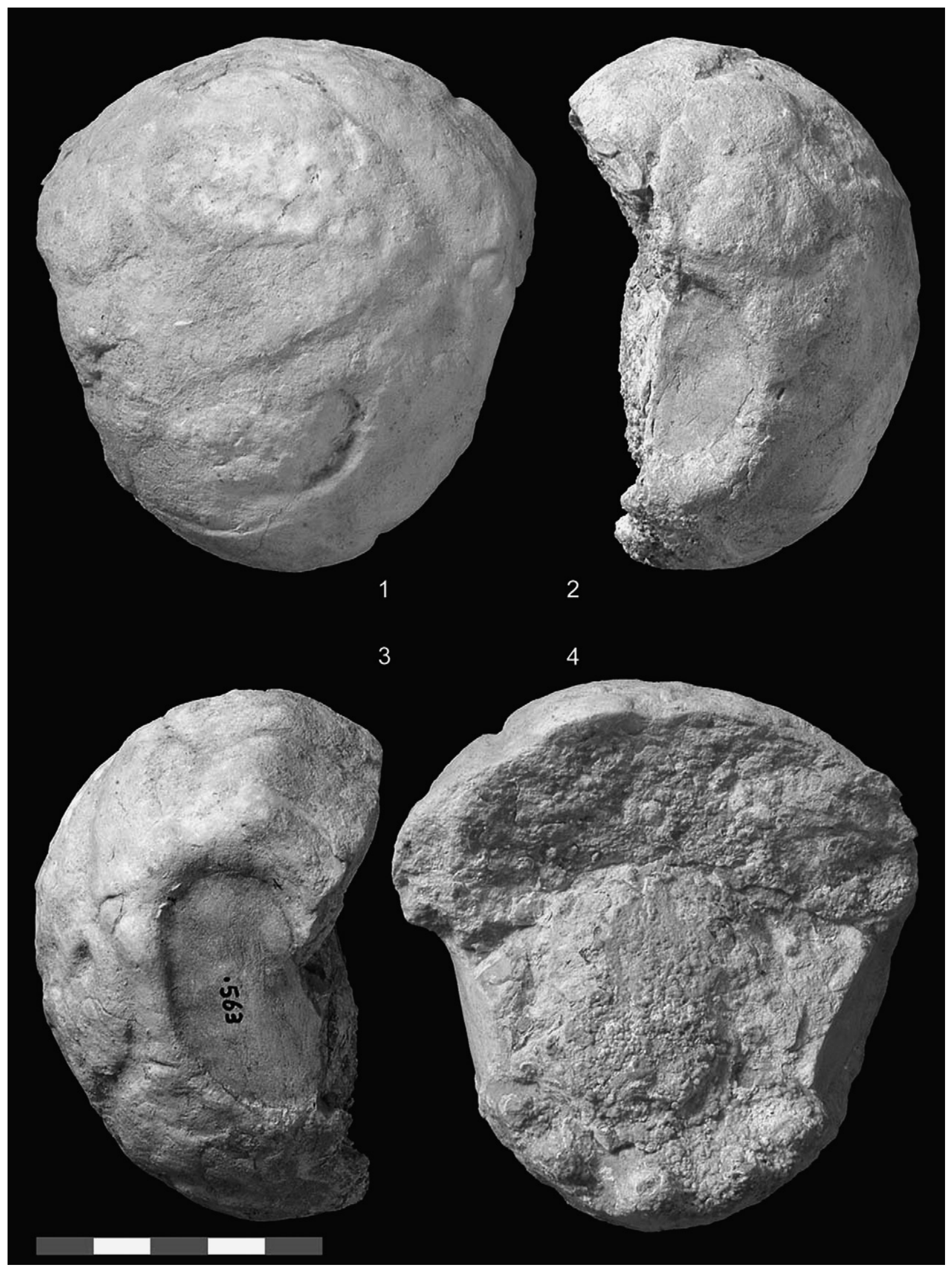

Fig. 6. Fagesia rudra (Stoliczka, 1865), specimen TA-S-563, from the Mammites nodosoides subzone of Tamajón. 1. Ventral view. 2 and 3. Lateral views. 4. Apertural view. Bar scale $=5 \mathrm{~cm}$ 
the Iberian Trough, it was obtained from the upper part of the Choffaticeras (Leoniceras) luciae subzone and the lower part of the M. nodosoides subzone of the North-Ebro and Guadarrama areas. Likewise, Wiedmann (1960a, 1964, 1979) cited a very doubtful specimen of F.tevesthensis in the middle Turonian of the North-Ebro Area.

Fagesia rudra (Stoliczka, 1865)

Fig. 5(2-5) and Fig. 6(1-4).

1865. Ammonites rudra -Stoliczka, p. 122, Pl. 60, Fig. 1, 1b.

1897. Olcostephanus rudra (Stoliczka) - Kossmat, p. 29

(136).

1960a. Fagesia rudra (Stoliczka) - Wiedmann, pp. 720-721.

1964. Fagesia rudra (Stoliczka) - Wiedmann, pp. 114-115.

1965. Fagesiarudra (Stoliczka)-Collignon, p. 48, PI.369,

Fig. 1678a; PI. 397, Fig. 1678b.

cf. 1973. Fagesia sp. cf. rudra (Stoliczka) - Matsumoto, p. 34.

1979. Fagesia rudra (Stoliczka) - Kennedy and Wright, p. 666, Pl. 82, Figs. $1,2$.

1984. Fagesia rudra (Stoliczka) - Meléndez-Hevia, p. 94,

PI. 10, Fig. 2a-C; PI. 12, Fig. 1.

aff. 1989. Fagesia aff. F. tevesthensis (Peron) - Lamolda

et al., Text-Fig. 3, Fig. 1a, b.

aff. 1991. Fagesia aff. rudra (Stoliczka) - Santamaría-

Zabala, p. 153, PI. 9, Fig. 1a, b.

aff. 1995. Fagesia aff. rudra (Stoliczka) - Santamaría-

Zabala, p. 50, PI. 2, Fig. 6.

2006. Fagesia rudra (Stoliczka) - Barroso-Barcenilla, p. 261, Pl. 36, Figs. d, e; PI. 37, Figs. a-f.

Type: Kennedy and Wright (1979) designated as lectotype the specimen illustrated by Stoliczka(1865: PI. 60, Figs. 1, 1b). Material and dimensions:

\begin{tabular}{lllll}
\hline & $\mathrm{D}$ & $\mathrm{H}(\%)$ & $\mathrm{B}(\%)$ & $\mathrm{U}(\%)$ \\
\hline TA-R-417 & rv1000 & rv350(35) & rv770 (77) & r260 (26) \\
TA-R-619 & rv760 & r285(38) & r7730(96) & rv195(26) \\
TA-R-623 & - & 294 & 875 & - \\
TA-S-563 & 989 & $359(36)$ & $933(94)$ & $343(35)$ \\
TA-S-565 & 709 & $298(42)$ & $654(92)$ & $186(26)$ \\
\hline
\end{tabular}

Description: involute ammonites with depressed and reniform whorl section, arched and continuous venter and flanks, and small and deep umbilici with flat, high and sloping walls and sharp umbilical shoulders. They reach their greatest whorl breadth close to the umbilical margins. Ornamentation is constituted by up to 40 low and fine ribs per whorl situated on the outer part of the flanks and the venter, and that weaken rapidly during ontogeny. They exhibit the early absence of umbilical tubercles, which is one of the main features of this unusual taxon.

Discussion: the difficult determination and classification of the species F. rudra (Stoliczka, 1865) has led to controversies among several authors. Kennedy and Wright (1979) considered that its weak and typical ribs are much more marked than those of other vascoceratids, but much more subdued than those of F. superstes (Kossmat, 1897). Furthermore, they indicated that the morphological features and the proportions of F. rudra and
F. bomba (Eck, 1909) seem to coincide, suggesting the possibility that they might be synonyms. Meléndez-Hevia (1984) considered that the differentiation of the two latter species should not be exclusively based on the presence or absence of umbilical tubercles, because these structures are commonly developed by vascoceratids but they tend to disappear during growth. Kennedy et al. (1987) indicated that the lack of umbilical tubercles in F. rudra, as well as in F. bomba, F. involuta Barber, 1957, and F. pervinquieri Böse, 1920 , could be a reason for assigning this species to the genus Vascoceras Choffat, 1898. Otherwise, Chancellor et al. (1994) pointed out that F. bomba could be a mereconspecific form of F. superstes.

On the question of whether F.bomba should be included in the synonymy of F. rudra or F. superstes, the sparse material obtainedin Spain onlyindicates thatthe respectivedistributions of these taxa are very similar. In our view it is preferable to maintain the specific division between these taxa. On the other side, the presence of slender umbilical tubercles in the smallest specimen presented here, the ammonite TA-S-565 (Fig. 5(2-5)), seems to be especially significant in terms of the generic assignation of F.rudra. Likewise, the horizontal and vertical distributions of $F$. rudra in the Iberian Trough are coincident with those of the remaining species of Fagesia Pervinquière, 1907, and are geographically more extended and stratigraphically higher than those of the members of Vascoceras. Thus, despite the early loss of umbilical tubercles, F.rudra should not be assigned to the genus Vascoceras.

Lamolda et al. (1989) classified as F. aff. F. tevesthensis (Peron, 1896) several specimens obtained from the lower and middle Turonian of Ganuza, in the Outer Navarro-Cantabrian Platform, that were subsequently attributed to $F$. aff. rudra by Santamaría-Zabala $(1991,1995)$ because they show slightly stouter ribs, arising individually on the umbilical shoulders and extending all across the flanks and the venter, than the lectotype of the species of Stoliczka. In our opinion, these ammonites exhibit morphological features closer to F. rudra than to F. tevesthensis.

Occurrence: F. rudra has been identified in the upper part of the lower Turonian and the lower part of the middle Turonian of India, Spain, Madagascar, France and, possibly, Japan. In the Iberian Trough, it has been recognised in undetermined levels of the North-Ebro Area and in the lower part of the Mammites nodosoides zone of the Guadarrama Area.

Fagesia mortzestus sp. nov.

Figs. 7(1-4) and 8(1-4).

1984. Fagesia cf. tehevensis (Peron) - Meléndez-Hevia, p. 92, PI. 11, Figs. 1a-c, 2 [only].

2006. Fagesia nov. sp. - Barroso-Barcenilla, p. 263, PI. 38, Figs. a-d; PI. 39, Figs. a-d; PI. 40, Fig. a, Text-Fig. 72.

Types: specimen TA-S-564 (Fig. 8(1, 2)) is designated here as holotype. The paratypes are specimens CS-R-593, TAR-582, TA-S-562 and TA-S-642.

Derivation of thename: it comes from the name of the ship in William Hope Hodgson's story titled "The ghost pirates" (1909). 


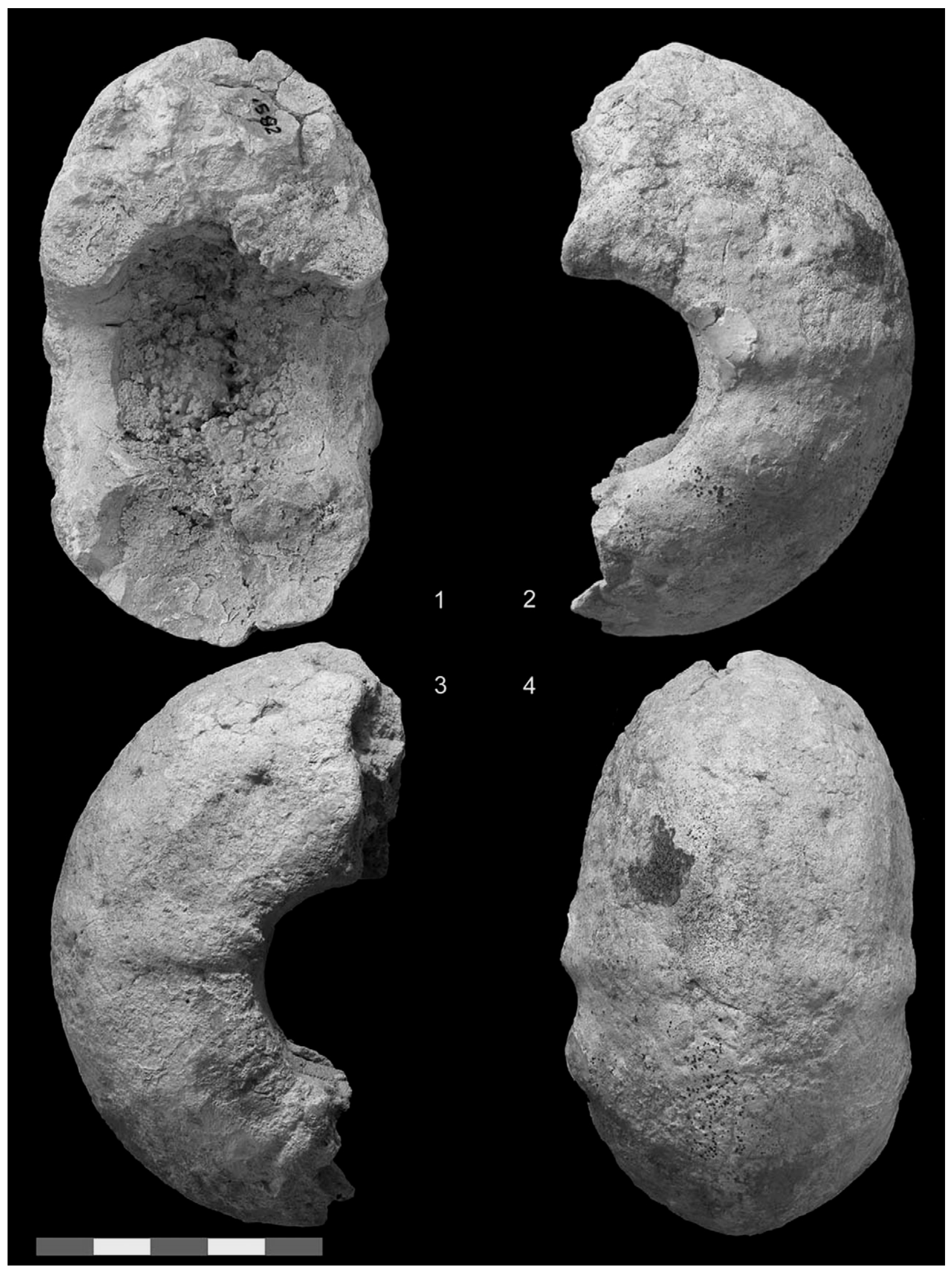

Fig. 7. Fagesia mortzestus sp. nov., specimen TA-R-582, paratype, from the Mammites nodosoides subzone of Tamajón. 1. Apertural view. 2 and 3. Lateral views. 4. Ventral view. Bar scale $=5 \mathrm{~cm}$. 


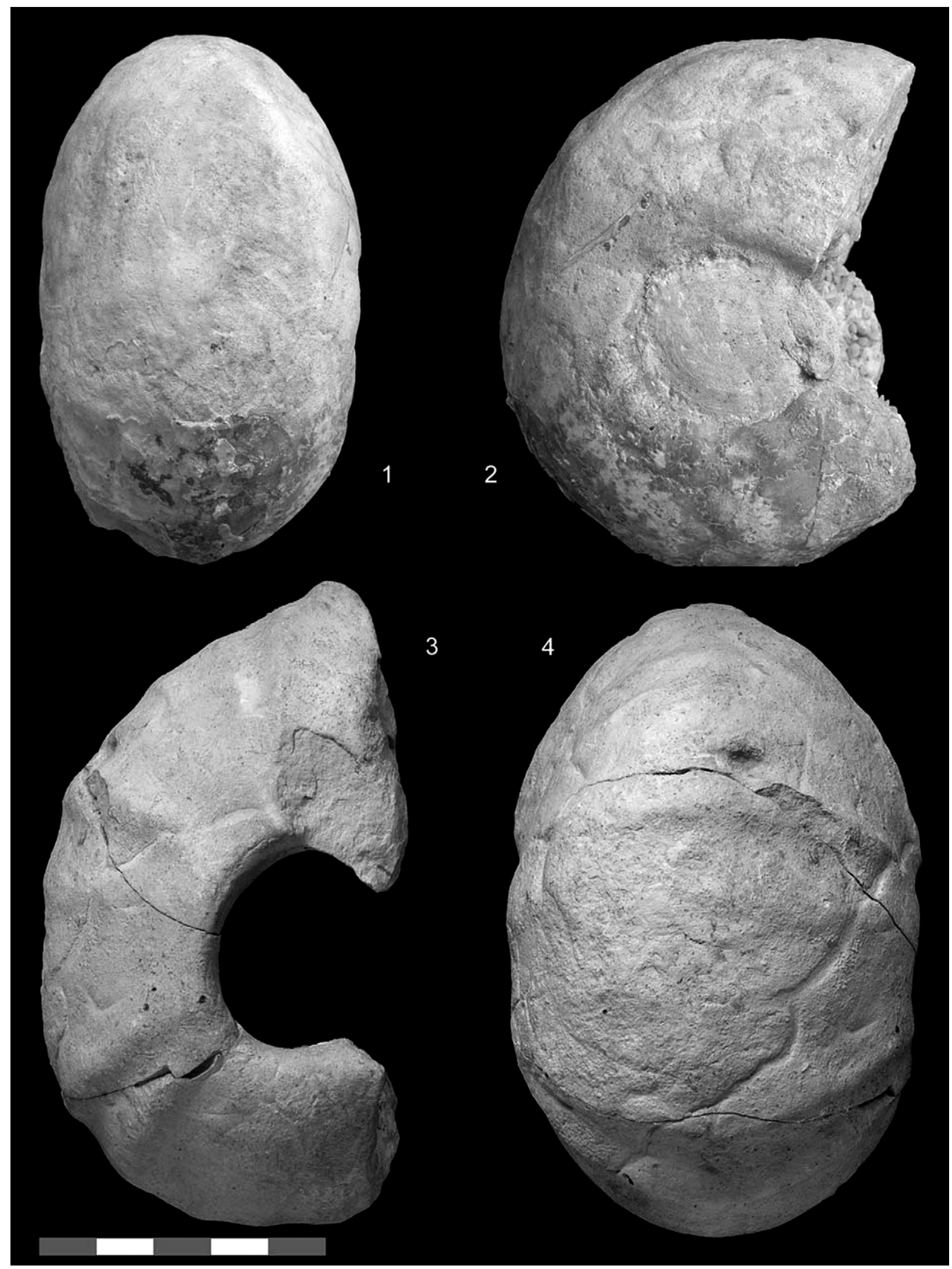

Fig. 8. Fagesiamortzestussp. nov.1, 2. SpecimenTA-S-564, holotype, from the Mammitesnodosoidessubzone of Tamajón. 1. Ventral view. 2. Lateral view. 3, 4. Specimen CS-R-593, paratype, from an unknown lower Turonian level of Somolinos. 3. Lateral view. 4. Ventral view. Bar scale $=5 \mathrm{~cm}$ 
Material and dimensions:

\begin{tabular}{lllll}
\hline & $\mathrm{D}$ & $\mathrm{H}(\%)$ & $\mathrm{B}(\%)$ & $\mathrm{U}(\%)$ \\
\hline CS-R-593 & 1215 & $510(42)$ & $786(65)$ & $352(29)$ \\
TA-R-582 & 1094 & $442(40)$ & $615(56)$ & $342(31)$ \\
TA-S-562 & 1174 & $488(42)$ & $766(65)$ & $350(30)$ \\
TA-S-564 & 1038 & $470(45)$ & $606(58)$ & $330(32)$ \\
TA-S-642 & 1099 & $467(42)$ & $712(65)$ & $304(28)$ \\
\hline
\end{tabular}

Diagnosis: moderately depressed and slightly involute medium-sized ammonites with whorl from semicircular to subtriangular in section, bearing marked ribs and rounded umbilical tubercles as ornamentation. Tectiform ventral region, slightly convex $\mathrm{fl}$ and moderately broad umbilici for the genus Fagesia Pervinquière, 1907. The ornamentation becomes subdued during growth. The tubercles weaken or disappear on the last whorls, whereas the ribs, which decline, normally persist over the adult body chamber, and can remain as the only ornamentation at maturity. Suture lines relatively simple for the genus, each one with three high and broad saddles per fl nk.

Discussion: within the genus, F. simplex Barber, 1957, has subtriangular whorl section and tubercles, but develops more evolute coiling, lacks ribs and its simplified suture lines prompted Chancellor et al. (1994) to suggest the inclusion of this species in Vascoceras Choffat, 1898. F. pervinquieri Böse, 1920 , shows morphology relatively close to that of F. mortzestus, but lacks umbilical tubercles, and F. involuta Barber, 1957, also presents slightly subtriangular whorls, although its shell is markedly globose, and it has a venter without ribs and a quite deep umbilicus. Among the remaining depressed members of Fagesia there are more ornamented taxa, as F. catinus (Mantell, 1822), F. superstes (Kossmat, 1897) and F. siskiyouensis Anderson, 1931; and less ornamented forms, like F. rudra (Stoliczka, 1865), F. boucheroni (Coquand, 1859), F. peroni Pervinquière, 1907, F. fleuryi Pervinquière, 1907, F. bomba (Eck, 1909) and F. levis Renz, 1982, but all of them possess rounded ventral regions. Thus, as their respective appearances are not tectiform, they can easily be distinguished from F. mortzestus. Otherwise, none of the relatively compressed forms of this genus, as F. tevesthensis (Peron, 1896), F. haarmanni Böse, 1920, F. pachydiscoides Spath, 1925, F.californica Anderson, 1931, F. shastensis Anderson, 1931 , and the unusual and eccentric F. lenticularis Freund and Raab, 1969, have important morphological resemblances with F. mortzestus.

In the case of other genera, subtriangular forms like the one developed by F. mortzestus at maturity are also characteristic for Choffaticeras (Choffaticeras) douvillei (Peron, 1896) and Vascoceras triangulare Faraud, 1940, which were considered as synonyms by Kennedy (1994). These two taxa, however, are more involute, present more complex suture lines and lack umbilical tubercles and ribs, which this new species has. Likewise, the whorls of V. obessum (Taubenhaus, 1920), V. ellipticum Barber, 1957, and V. costatum tectiforme (Barber, 1957) have markedly triangular section, but these taxa are usually poorly ornamented with weaker and less persistent tubercles, and their umbilici are commonly narrower than the ones of F. mortzestus.

Occurrence: the specimens of this new species have been collected from the M. nodosoides subzone in localities of Somolinos, level 16 of Meléndez-Hevia (1984), and Tamajón, level 18 of Barroso-Barcenilla (2006), in the Guadarrama Area, located in the Iberian Trough, Spain.

Fagesia superstes (Kossmat, 1897)

Fig. 9(1, 2).

1897. Olcostephanus superstes-Kossmat, p. 26(133), PI. 4

(17), Fig. 1a-c.

1897. Olcostephanus superstes Kossmat-Peron, p. 84

aff. 1898. Ammonites sp. indet. aff. superstes (Kossmat) -

Choffat, p. 69, PI. 10, Fig. 4.

1903a. Pachyceras superstes (Kossmat) - Pervinquière, pp. 96, 99, 101.

1907. Fagesia superstes (Kossmat)-Pervinquière, p. 322 , PI. 20, Figs. 1-4a, Text-Fig. 122 (included the tunisiensis and spheroidalis varieties).

1909. Fagesia superstes (Kossmat) - Eck, p. 182.

1912. Fagesia superstes (Kossmat)-Douvillé, p. 300, TextFig. 18.

1931. Fagesia superstes (Kossmat)-Basse, p. 39.

1940. Fagesia superstes (Kossmat)-Basse, p. 459.

1957. Fagesia superstes (Kossmat) - Moore in Wright, p. L420, Text-Fig. 541/2a-C.

1965. Fagesia superstes spheroidalis Pervinquière - Collignon, p. 46, PI. 395, Fig. 1677.

cf. 1969. Fagesia cf. F. superstes (Kossmat) - Freund and

Raab, p. 35, Text-Fig. 7f.

non 1969 Fagesia superstes (Kossmat) var. tunisiensis Pervinquière-Thomel, p. 116, Pl. d, Figs. 1, 2; Pl. e, Figs. 1, 2 (= F. catinus).

1978. Fagesia spheroidalis Pervinquière - Matsumoto and Muramoto, p. 282, PI. 39, Fig. 1, Text-Fig. 2.

? aff. 1982. Fagesia aff. superstes (Kossmat) - Renz, p. 78, PI. 22, Fig. 19a, b; PI. 23, Fig. 4a, b, Text-Fig. 59b.

1983. Fagesia superstes (Kossmat) - Cobban and Hook,

p. 16, PI. 3, Figs. 1, 2; PI. 13, Figs. 6-11, Text-Fig. 12.

1984. Fagesia superstes (Kossmat) - Meléndez-Hevia, p. 91, PI. 10, Fig. 1a-C.

cf. 1989. Fagesia cf. superstes (Kossmat) - Luger and

Gröschke, p. 372, PI. 40, Figs. 1, 2.

aff. 1990. Fagesia aff. superstes (Kossmat) - Zaborski, Figs.

32, 33.

1990. Fagesia superstes (Kossmat) - Robaszynski et al.,

p. 266, PI. 20, Fig. 1a, b; PI. 21, Fig. 2a, b.

1994. Fagesia superstes (Kossmat) - Chancellor et al., p. 56,

PI. 13, Figs. 1, 2; PI. 15, Figs. 4-9; PI. 32, Fig. 4.

1996. Fagesia superstes (Kossmat) - Kaesler in Wright, p. 176, Text-Fig. 136/1a-c.

1997. Fagesia superstes (Kossmat) - Wiese, PI. 2, Figs. 1, 2.

2001. Fagesia superstes (Kossmat) - Callapez and Ferreira,

p. 84, PI. 12, Fig. 3, Text-Figs. 23.7-8.

2006. Fagesia superstes (Kossmat) - Barroso-Barcenilla, p. 265 , Pl. 40 , Figs. b-d. 


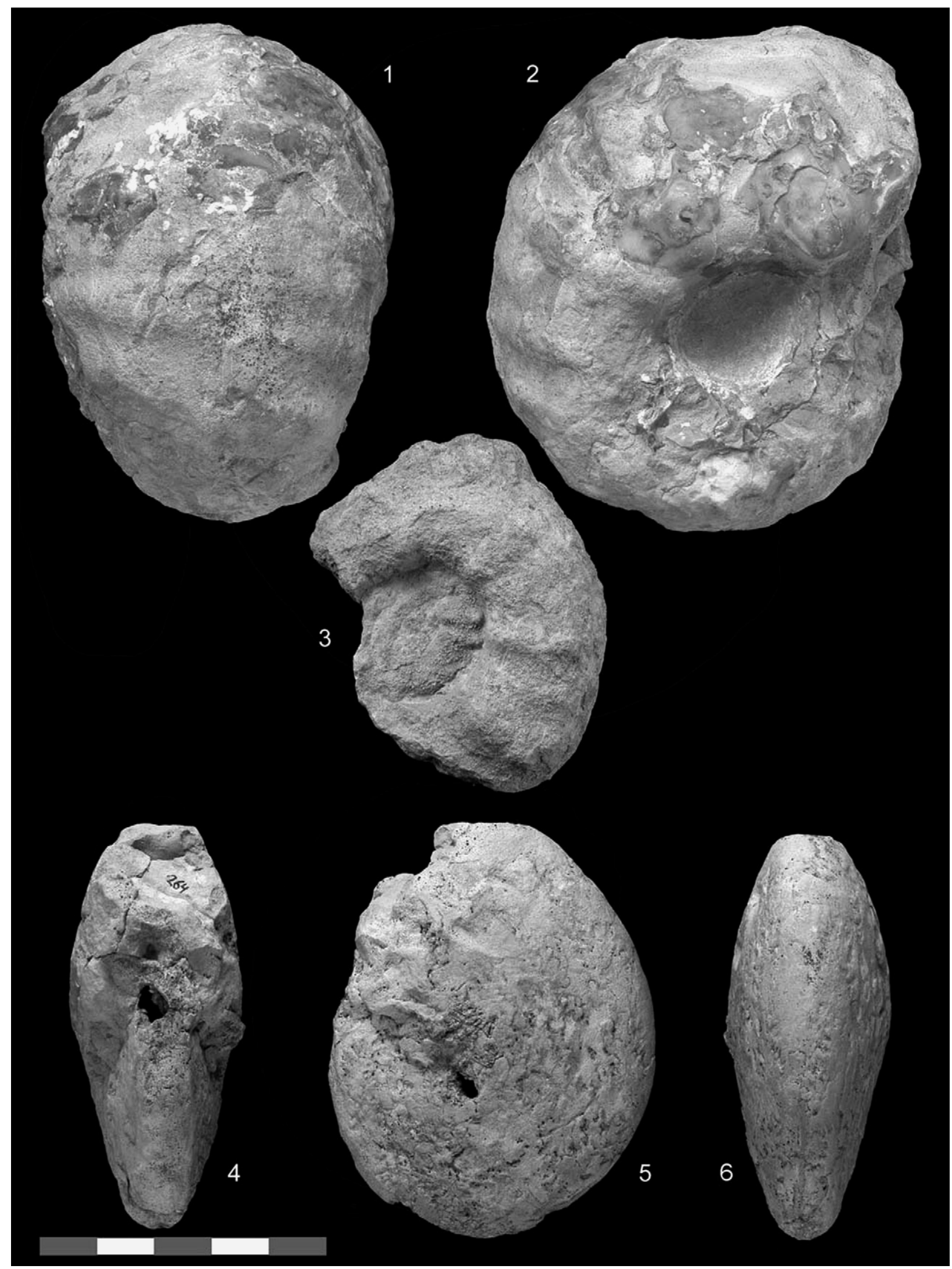

Fig. 9. 1, 2. Fagesia superstes (Kossmat, 1897), specimen TA-R-584, from the Mammites nodosoides subzone of Tamajón. 1. Ventral view. 2. Lateral view. 3. Fagesia pachydiscoides Spath, 1925, specimen CB-R-27, from an unknown lower Turonian level of Condemios, lateral view. 4, 5, 6. Neoptychites cephalotus (Courtiller, 1860), specimen PSR-264, from an unknown lower Turonian level of Soncillo. 4. Apertural view. 5. Lateral view. 6 . Ventral view. The $5 \mathrm{~cm}$ bar scale only applies to Figs. 1-3; Figs. 4-6, $\times 3 / 4$ with respect to the bar scale. 
Type: the lectotype designated by Chancellor et al. (1994) is the original of Kossmat (1897: p. 26, PI. 6(17), Fig. 1), probably from Odium, India.

Material and dimensions:

\begin{tabular}{|c|c|c|c|c|}
\hline & D & $\mathrm{H}(\%)$ & B (\%) & U (\%) \\
\hline FT-S-697 & 836 & rv318(38) & - & rv340 (41) \\
\hline FT-S-815 & 705 & $312(44)$ & $545(77)$ & rv240 (34) \\
\hline MS-7 & 609 & 281 (46) & $514(84)$ & $215(35)$ \\
\hline PU-S-290 & 848 & 345 (41) & rv540 (64) & $344(41)$ \\
\hline TA-R-419 & 580 & 220 (38) & rv365 (63) & $198(34)$ \\
\hline TA-R-438 & rv578 & rv210(36) & rv410 (71) & rv214 (37) \\
\hline TA-R-584 & 953 & $414(43)$ & $630(66)$ & $228(24)$ \\
\hline TA-S-580 & 650 & $264(41)$ & $565(87)$ & $255(39)$ \\
\hline
\end{tabular}

Description: cadiconic and slightly evolute or involute specimens with arched ventral region and moderately broad umbilici of high and vertical walls and rounded margins. They have a depressed and rounded subreniform whorl section, whose width is twice its height. Their marked ornamentation is made up by prominent and coarse ribbing and strong umbilical tubercles, each of them giving rise to two slightly prorsiradiate ribs that cross the flanks and continue without interruption over the ventral region. They possess relatively complex suture lines, with high saddles and asymmetric and bifid first lateral lobes. The rest of their lobes are commonly bifid.

Discussion: Kossmat (1897) described his new Olcostephanus superstes, but he did not establish subspecific divisions in this taxon. Pervinquière (1907) proposed his new varieties $F$. superstes tunisiensis and F. superstes spheroidalis, which present some slight differences from Kossmat's original. The first variety can be distinguished by having a rather more depressed whorl section and only 10-12 umbilical tubercles per whorl. F. superstes spheroidalis presents a rounded ventral region and a narrower umbilicus with only ten umbilical tubercles per whorl. In this respect it seems that the differences described above are not too significant, and that although certain authors, like Matsumoto and Muramoto (1978), gave specific status to the variety spheroidalis, it is preferable to consider these two morphological types of Pervinquière (1907) as simple intraspecific variants, as indicated by Cobban and Hook (1983) and Chancellor et al. (1994), among others.

Apart from strongly ornamented specimens that are more convergent with the holotype of F. superstes, other morphologies with weak ribs and relatively broad umbilici seem to be included within this species, like the ammonite of Peron (1897: p. 84) illustrated by Chancellor et al. (1994: PI. 32, Fig. 4). These features are also very close to those of the specimens of F. aff. superstes of Renz (1982), although Kennedy et al. (1987) preferred to include them in the synonymy of $F$. catinus (Mantell, 1822).

F. superstes can easily be distinguished from F. catinus and F. pachydiscoides Spath, 1925, by its more globose morphology and its narrower umbilici. F. rudra (Stoliczka, 1865) almost lacks umbilical tubercles and has weak ribs that rapidly disappear during ontogeny, as opposed to F. superstes. F. haarmanni Böse, 1920, presents certain ornamentation that disappears during the early growing stages, whereas F. involute
Barber, 1957, and Fagesia peroni Pervinquière, 1907, lack ribs.

With regard to the phylogeny of $F$. superstes, this species seems to becloselylinked to F.tevesthensis, from which itmay be derived by broadening of the whorl and a decline in ornamentation.

Occurrence: it has been found in biostratigraphic units equivalent to the lower Turonian $M$. nodosoides standard zone and in the lower part of the middle Turonian of India, Algeria, Portugal, Tunisia, Madagascar, Syria, Israel, Japan, the USA, Spain and, probably, Egypt and Venezuela. In the Iberian Trough, F. superstes occurs in the $M$. nodosoides zone of the Central Sector, whereas one member of this species has been collected from the same biostratigraphic unit of the NorthCastilian Sector. It is the latest member of the genus Fagesia Pervinquière, 1907 identified in the present work.

Fagesia pachydiscoides Spath, 1925

Fig. 9(3).

1855. Ammonites catinus Mantell - Sharpe, p. 29, PI. 13, Fig. 1a, b.

1925. Fagesia pachydiscoides - Spath, p. 198.

1978. Fagesia pachydiscoides Spath - Kennedy and Hancock, p. V19.

1981. Fagesia pachydiscoides Spath - Wright and Kennedy, p. 97, Text-Fig. 37.

1991. Fagesia pachydiscoides Spath - Santamaría-Zabala, p. 150, PI. 9, Fig. 4.

cf. 1991. Fagesia cf. pachydiscoides Spath - SantamaríaZabala, p. 152, PI. 9, Fig. 5.

1992. Fagesia catinus pachydiscoides [sic] Spath-Thomel, p. 231, PI. 87, Fig. 1; PI. 88; PI. 91, Figs. 1, 2; PI. 92, 95; PI. 96 , Fig. 2.

1992. Fagesia catinus niciensis - Thomel, p. 232, PI. 96, Fig. 1; PI. 97-98; PI. 99, Fig. 5.

1995. Fagesia pachydiscoides Spath - Santamaría-Zabala, p. 49, Pl. 2, Fig. 5.

2006. Fagesia pachydiscoides Spath - Barroso-Barcenilla, p. 268 , Pl. 40 , Fig. e.

Type: the holotype by monotypy is specimen 88583 of the BMNH, original of Sharpe (1855) and from the $M$. nodosoides zone of Wiltshire, UK.

Material and dimensions:

\begin{tabular}{lllll}
\hline & $\mathrm{D}$ & $\mathrm{H}(\%)$ & $\mathrm{B}(\%)$ & $\mathrm{U}(\%)$ \\
\hline CB-R-27 & 675 & $\mathrm{r} 232(34)$ & rv230 (34) & r241 (36) \\
\hline
\end{tabular}

Description: evolute specimen with rounded or subreniform whorl section hardly higher than wide, and relatively large umbilici with arched margins. The venter and flanks describe a continuous curved contour line, which makes it very difficult to establish one limiting trait separating them. The tubercles and, especially, the ribs weaken with growth, becoming an almost smooth or little ornamented body chamber.

Discussion: among other authors, Wright and Kennedy (1981), Chancellor (1982) and Kennedy et al. (1987) suggested that F.pachydiscoides Spath, 1925, maywell beasynonym of 
F. catinus (Mantell, 1822), and Thomel (1992) considered that the former taxon is a mere subspecies of the latter. The records of both taxa from the Iberian Trough are too poor to provide additional information to help in solving this matter. However, the morphologies of F. catinus and F. pachydiscoides seem easily distinguishable, which is why we have opted to maintain their specific division, agreeing with Santamaría-Zabala (1991, 1995). On the other hand, the ammonites assigned by Thomel (1992) to his new subspecies F. catinus niciensis seem to be evolute and compressed specimens of F. pachydiscoides.

The small or almost non-existent depression of the whorl, quite uncommon within the members of the genus Fagesia Pervinquière, 1907, and the evolute coiling allows for identification of this species. F.catinus shows a more depressed and involute whorl section, whereas $F$. superstes exhibits a coarser and more persistent ornamentation, and a higher number of umbilical tubercles per whorl.

Occurrence: Lower Turonian of the UK, Spain and France. In the Iberian Trough, the specimen identified by SantamaríaZabala $(1991,1995)$ and the one presented herein come from undetermined lower Turonian levels. In the first case of the Outer Navarro-Cantabrian Platform, and in the second case of the Guadarrama Area.

Neoptychites Kossmat, 1895

[Betiokytes Collignon, 1965, p. 56, type species by original designation Hemitissotia (Betiokytes) besairiei Collignon, 1965. Pseudoneoptychites Leanza, 1967, p. 202, type species by original designation Pseudoneoptychites andinus Leanza, 1967].

Type species: Ammonites telinga Stoliczka, 1865, synonym of Ammonites cephalotus Courtiller, 1860. Several authors indicated that the designation is original. However, Kossmat (1895) did not clearly select the species of Stoliczka as the type of his newgroup. Solger (1904: p. 105) was the firstauthor to consider A. telinga as generotype of Neoptychites, as indicated by Chancellor et al. (1994) and Kaesler in Wright (1996).

Diagnosis: evolute and medium-sized group with variably compressed whorls, reaching their greatest breadth near the arched umbilical margins, and small crateriform umbilici occasionally covered by an umbilical lid. Its venter is narrow and rounded or slightly tabulate, and its flanks are flat. Some of its species may haveribs, which are annular, broad and low, and constrictions or small and elongated umbilical tubercles on the inner whorls. These ornamental elements disappear quite soon, leaving the outer whorls totally smooth. The adult body chamber usually has contracted apertures. Although the suture lines of this genus are highly variable, they are among the most complex ones of the family Vascoceratidae Douvillé, 1912, presenting large, broad and low sutural elements.

Discussion: the morphology of its shell, with the typical aperture, and the absence of tubercles from early ontogenetic stages clearly distinguishes this genus from Vascoceras Choffat, 1898. The suture lines are markedly simpler than those of Choffaticeras Hyatt, 1903. Otherwise, Neoptychites bears some resemblances to Thomasites, as Pervinquière (1907) emphasised when he described his new genus. Considering this,
Freund and Raab (1969) noted that, although the adult morphology of Neoptychites may be similar to that of Thomasites, they have markedly different ornamentations and suture lines. Chancellor et al. (1994) wrote a detailed description of the features distinguishing both genera.

Although, as indicated above, the identification of Neoptychites is relatively easy, the differentiation between the species assigned to this genus can be quite hard, as their distinction is only based on the dimensions of the whorl breadth and certain details of the suture lines and of the juvenile ornamentation that can hardly be observed in some mature specimens.

In relation to the synonymy of the genus, Kennedy and Wright (1979) considered that the description of Pseudoneoptychites is based on a juvenile specimen of Neoptychites. Therefore, they indicated that the group of Leanza should be considered as a mere synonym of the genus of Kossmat. These authors also preferred to regard Betiokytes as a subgenus of Neoptychites that groups species with subtabular venter and suture lines with wide, rounded or slightly incised saddles. Nevertheless, most subsequent authors opted for not differentiating subgenera within Neoptychites. Kaesler in Wright (1996) also included Franciscoites in the synonymy of Neoptychites, although he did not justify the reasons for this decision. In our opinion, the original descriptions of Betiokytes and of Pseudoneoptychites are, respectively, based on an adult specimen and on several juvenile members of Neoptychites. Likewise, the scarce relevance of the diagnostic features of Franciscoites remarked on by its author does not seem to justify the generic separation of this group. Therefore, Betiokytes, Pseudoneoptychites and, possibly, Franciscoites should simply be regarded as synonyms of Neoptychites.

Concerning the phylogeny of the genus, many authors remarked on the isolated position of Neoptychites within the Vascoceratidae, because transitional forms with other genera were never identified. Some palaeontologists, like Pervinquière (1907), Diener (1925) and Basse (1931), excluded Neoptychites from the Vascoceratidae. Nevertheless, nowadays it is a commonly accepted opinion that the morphologic proximity and the phylogenetic relationship of Neoptychites to other members of the Vascoceratidae are both valid arguments for attributing the genus of Kossmat to the family of Douvillé.

Occurrence: it has been identified from lower to upper Turonian of France, Spain, Portugal, Morocco, Algeria, Tunisia, Egypt, Cameroon, Nigeria, Madagascar, Syria, Israel, India, Japan, the USA, Mexico, Trinidad and Tobago, Brazil, Colombia and Venezuela, reaching its maximum abundance in the lower part of the middle Turonian. The specimens of Neoptychites from the Iberian Trough have been obtained almost exclusively within the Mammites nodosoides zone and the middle Turonian from the Outer Navarro-Cantabrian Platform and the North-Castilian Sector.

Neoptychites cephalotus (Courtiller, 1860)

Fig. 9(4-6) and Fig. 10(1-3).

1850. Ammonites santonensis - d'Orbigny, p. 212.

1860. Ammonites cephalotus - Courtiller, p. 248, PI. 2, Figs. $1,4$. 


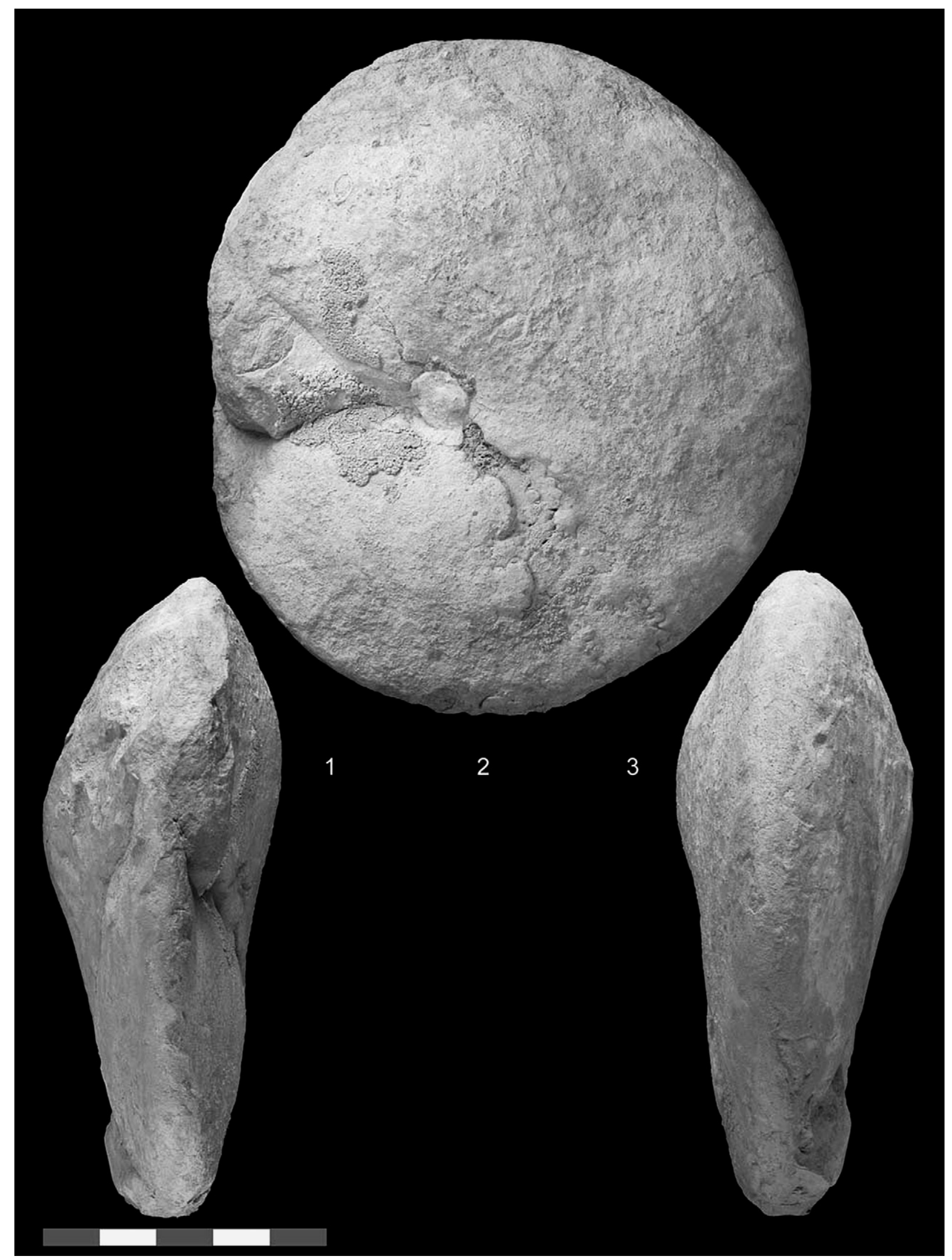

Fig. 10. Neoptychites cephalotus (Courtiller, 1860), specimen PU-S-382, from the Mammites nodosoides zone of Puentedey, $x 3 / 4$ with respect to the $5 \mathrm{~cm}$ bar scale. 1. Apertural view. 2. Lateral views. 3. Ventral view. 
1865. Ammonites xetra - Stoliczka, p. 124, PI. 61, Figs. 1, 2. 1865. Ammonites telinga - Stoliczka, p. 125, PI. 62,

Figs. 1, 2.

1867. Ammonites cephalotus Courtiller - Courtiller, p. 3,

PI. 1, Figs. 1-3; PI. 2, Figs. 1, 2.

1889. Pachydiscus africanus-Peron, p. 28, PI. 17, Figs. 9, 10.

1895. Neoptychites telinga (Stoliczka) - Kossmat, p. 71,

PI. 7, Fig. 1.

1895. Neoptychites xetra (Stoliczka) - Kossmat, p. 72.

1896. Neoptychites cephalotus (Courtiller) - de Grossouvre,

p. 86.

1896. Neoptychitestelinga (Stoliczka)-Peron, p. 38, PI. 6,

Fig. 1; PI. 7, Fig. 1; PI. 17, Fig. 13.

1897. Pulchellia perovalis-vonKoenen, p. 10, PI. 1,Fig. 3;

PI. 2, Fig. 6.

? 1903a. Neoptychites cf. N. xetra (Stoliczka) - Pervinquière, p. 101.

1903b. Neoptychites cephalotus (Courtiller) - Pervinquière, fiche 5, 5c.

1904. Neoptychites telingaeformis - Solger, p. 108, PI. 3,

Figs. 2, 3, Text-Figs. 9-17 (included the elegans, palmata and discrepans varieties).

1904. Neoptychitescrassus-Solger, p. 119, PI. 3, Fig. 5a, b,

Text-Figs. 18, 19 (included the crassus and asymetrica varieties).

1904. Neoptychites perovalis (von Koenen) - Solger, p. 122.

1907. Neoptychites cephalotus (Courtiller)-Pervinquière,

p. 393, PI. 27, Figs. 1-4, Text-Fig. 152.

? 1907. Neoptychites xetriformis - Pervinquière, p. 398,

PI. 27, Figs. 5-7, Text-Figs. 153, 154.

1907. Neoptychites gourguechoni - Pervinquière, p. 400,

PI. 27, Figs. 8, 9, Text-Figs. 155, 156.

1912. Neoptychites cephalotus (Courtiller) - Roman, p. 13,

PI. 1, Fig. 2.

? aff. 1920. Neoptychites aff. xetriformis Pervinquière -

Böse, p. 223, PI. 18, Figs. 9, 11, Text-Fig. 7.

? 1920. Neoptychites xetriformis Pervinquière - Tauben-

haus, p. 45, PI. 5, Fig. 1.

1931. Neoptychites cephalotus (Courtiller) - Basse, p. 34,

PI. 4, Fig. 9; PI. 11, Fig. 5a, b.

? 1931. Neoptychites xetriformis Pervinquière-Basse, p. 35,

PI. 12, Fig. 1.

1931. Neoptychites cephalotus (Courtiller) - Basse, p. 47,

Text-Fig. 2a, b.

? 1931. Neoptychites sp. aff. gourguechoni Pervinquière-

Adkins, p. 57, Pl. 2, Figs. 18, 20.

1932. Neoptychites telingaeformis Solger var. discrepans

Solger-Riedel, p. 123, PI. 26, Fig. 5.

1932. Neoptychites perovalis (von Koenen) - Riedel, p. 123,

PI. 26, Fig. 7.

1935. Neoptychites cephalotus (Courtiller) - Karrenberg,

p. 143 , Fig. 4.

1939. Neoptychites cephalotus (Courtiller) - Basse, p. 47,

Text-Fig. 2.

1940. Neoptychites cephalotus (Courtiller)-Basse, p. 456,

PI. 5, Fig. 4a, b.
? cf. 1954. Neoptychites cf. N. xetriformis Pervinquière Kummel and Decker, p. 315, PI. 32, Fig. 3, Text-Figs. 5, 6.

1955. Neoptychites perovalis (von Koenen) - Reyment,

p. 66, PI. 10, Fig. 4, Text-Fig. 29.

1955. Neoptychites telingaeformis Solger - Reyment, p. 66,

PI. 15, Fig. 1, Text-Fig. 30 [non Pl. 11, Fig. 4].

1955. Neoptychites crassus Solger-Reyment, p. 67.

1957. Neoptychites cephalotus (Courtiller) - Moore in

Wright, p. L422, Text-Fig. 540/6a, b.

1960a. Neoptychites cephalotus (Courtiller) - Wiedmann,

pp. 711-712, 715, 719, 721.

? 1963b. Neoptychites xetriformis Pervinquière - Powell, p. 1229, PI. 171, Figs. 2-4, Text-Fig. 5b.

1964. Neoptychites cephalotus (Courtiller) - Wiedmann, pp. 111-112, 114, 115.

1965. Neoptychites cephalotus (Courtiller) - Collignon, p. 58, PI. 401, Fig. 1685.

1966. Neoptychites cephalotus (Courtiller) - Collignon,

p. 43 , PI. 24 , Fig. 1a, b.

1969. Neoptychites cephalotus (Courtiller) - Freund and

Raab, p. 48.

? 1969. Neoptychites xetriformis Pervinquière - Freund and

Raab, p. 48.

cf. 1969. Neoptychites cf. N.xetra (Stoliczka)-Freund and

Raab, p. 49, Text-Fig. 10d.

? 1969. Neoptychitessp. 1-Freund and Raab, p. 49, Text-

Fig. 10e, $\mathrm{f}$.

? 1969. Neoptychites sp. 2-Freund and Raab, p. 59, Text-

Fig. $10 \mathrm{~g}$.

? 1972. Neoptychites xetriformis Pervinquière - Cobban and

Scott, p. 89, PI. 30, Figs. 2-6, Text-Fig. 48.

cf. 1972. Neoptychites cf. N. cephalotus (Courtiller) -

Cobban and Scott, p. 90, PI. 30, Fig. 9, Text-Figs. 49, 50.

1975a. Neoptychites cephalotus (Courtiller) - Wiedmann,

p. 141.

1978. Neoptychites cephalotus (Courtiller) - Matsumoto,

p. 197, Pl. 1, Fig. 1, Text-Fig. 1.

1978. Neoptychites (Neoptychites) cephalotus (Courtiller)-

Wiedmann and Kauffman, PI. 10, Fig. 2.

1979. Neoptychites (Neoptychites) cephalotus (Courtiller) -

Wiedmann, PI. 10, Fig. 2.

1979. Neoptychites cephalotus (Courtiller) - Kennedy and

Wright, p. 670, PI. 82, Figs. 3-5; PI. 83, Figs. 1-3; PI. 84, Fig. 3;

PI. 85, Figs. 1-5; PI. 86, Figs. 4, 5, Text-Fig. 2.

? 1979. Neoptychites xetriformis Pervinquière - Kennedy

and Wright, p. 679, PI. 84, Figs. 1, 2; PI. 86, Figs. 1-3.

1982. Neoptychites cephalotus (Courtiller) - Matsumoto and

Obata, p. 78, Pl. 4, Fig. 1a, d.

1982. Neoptychites cephalotus (Courtiller) - Amédro and

Badillet in Robaszynski et al., p. 131, PI. 2, Fig. 1a, b.

? 1982. Neoptychites xetriformis Pervinquière - Amédro

and Badillet in Robaszynski et al., p. 131, Pl. 2, Figs.

$2 \mathrm{a}, \mathrm{b}$.

aff. 1982. Neoptychites aff. crassus Solger - Renz, p. 88,

PI. 26, Fig. 16a, b.

aff. 1982. Neoptychites aff. telingaeformis discrepans Solger-Renz, p. 88, PI. 26, Fig. 17. 
?1982. Neoptychitestransitorius-Renz, p. 87, PI. 26, Figs. 15a, b, 18a, b, Text-Figs. 66a, 65d.

? 1982. Neoptychites xetriformis Pervinquière - Renz, p. 88, PI. 26, Fig. 19a, b, Text-Fig. 67.

? 1983. Neoptychites cephalotus (Courtiller) - Cobban and Hook, p. 14, PI. 3, Figs. 9-11; PI. 9-12, Text-Fig. 11.

1985. Neoptychites cephalotus (Courtiller) - Amédro and Hancock, Fig. 7c, d.

1987. Neoptychites cephalotus (Courtiller) - Zaborski, p. 43, Figs. 31, 32.

?1988. Neoptychitescephalotus(Courtiller)-Kennedyand

Cobban, p. 604, PI. 3, Figs. 3, 4, 8, 9.

cf. 1989. Neoptychites cf. cephalotus (Courtiller)-Kennedy et al., p. 84.

? 1989. Neoptychites cephalotus (Courtiller) - Cobban et al., p. 54, Figs. 54, 88bb-ff.

1990. Neoptychites cephalotus (Courtiller)-Zaborski, Fig. 31.

1990. Neoptychites cephalotus (Courtiller) - Robaszynski et al., p. 266, Pl. 20, Figs.?2a, b, 3a, b; PI. 21, Fig.? 3a, b.

? 1992. Neoptychites xetriformis Pervinquière - Thomel, p. 234, Pl. 103, Figs. 1-3.

1994. Neoptychites cephalotus (Courtiller) - Chancellor et al., p. 70, Pl. 16, Figs.?1-3, 4-6, ?7-9; Pl. 17, Figs. 1-5; PI. 18, Figs. 1-3; PI. 26, Figs. 2-4.

1994. Neoptychites gr. cephalotus (Courtiller) - Meister et al., p. 206, PI. 14, Fig. 4, Text-Fig. 10.

? 1994. Neoptychites xetriformis Pervinquière - Kassab, p. 121, Fig. 5(5-7).

1996. Neoptychites gr. cephalotus (Courtiller)-Meister and Abdallah, p. 11, PI. 3, Fig.?2; PI. 5, Fig. 3; PI. 6, Fig. 1, TextFigs. $5 f, g$.

1996. Neoptychites cephalotus (Courtiller) - Kaesler in Wright, p. 176, Text-Fig. 136/2a, b.

1998. Neoptychites cephalotus (Courtiller) - Callapez, PI. 13, Figs. 7, 8; PI. 14, Fig. 6.

2001. Neoptychites cephalotus (Courtiller) - Callapez and Ferreira, p. 89, PI. 13, Figs. 7, 8; PI. 14, Fig. 6, Text-Figs. 23.11, 12.

2005. Neoptychites gr. cephalotus (Courtiller) - Meister and Abdallah, p. 136, PI. 15, Figs. 1, ?2; PI. 16, Fig. 1; PI. 20, Fig. 1.

2006. Neoptychites cephalotus (Courtiller) - BarrosoBarcenilla, p. 273, PI. 41, Figs. a-e; PI. 42, Figs. a-c, TextFig. 74.

Type: the lectotype designated by Kennedy and Wright (1979: p. 671, Pl. 83, Figs. 1-3) is the specimen 631 of the CS, original of Courtiller (1860: PI. 2, Figs. 1, 2), collected from the middle Turonian of the surroundings of Saumur, France.

Material and dimensions:

\begin{tabular}{lllll}
\hline & $\mathrm{D}$ & $\mathrm{H}(\%)$ & $\mathrm{B}(\%)$ & $\mathrm{U}(\%)$ \\
\hline FT-R-742 & 1325 & $713(54)$ & $576(43)$ & $105(8)$ \\
PS-R-264 & 1006 & $596(59)$ & $426(42)$ & $69(7)$ \\
PU-R-248 & 1235 & $627(51)$ & $417(34)$ & $61(5)$ \\
PU-S-382 & 1640 & $855(52)$ & $622(38)$ & $139(8)$ \\
PU-S-384 & 1054 & $521(49)$ & r290(28) & $72(7)$ \\
\hline
\end{tabular}

Description: involute and compressed specimens with suboval or subtriangular whorl section and smooth surface at maturity. They have rounded and narrow ventral region, convergent and flat or slightly convex flanks and very small umbilici. Some mature specimens develop a broad bulge on each flank of the body chamber, which provides them with a typical fusiform profile. They present relatively variable suture lines.

Discussion: de Grossouvre (1896), like almost all the authors who have studied this species, considered that A. telinga Stoliczka, 1865, can be included in the normal morphological variability of Neoptychites cephalotus (Courtiller, 1860). Pervinquière (1907) noted that Pachydiscus africanus Peron, 1889, A. xetra Stoliczka, 1865, and $N$. telingaeformis Solger, 1904, have many resemblances to $N$. cephalotus, and included the first taxon and, with doubts, the third one in the synonymy of this species. Kennedy and Wright (1979) agreed with Pervinquière (1907), and indicated that the original descriptions of $A$. xetra and P. africanus would be based respectively on a broad mature specimen and on a juvenile member of $N$. cephalotus. They also considered that $N$. telingaeformis and $N$. crassus Solger, 1904, including its respective varieties, as well as Pulchellia perovalis von Koenen, 1897 , and $N$. gourguechoni Pervinquière, 1907, are synonyms. These taxonomic suggestions were subsequently maintained by Kennedyand Cobban (1988) and Kennedyetal. (1989), among others. Likewise, Kennedy and Wright (1979) illustrated the holotype of $A$. santonensis d'Orbigny, 1850. They also transcribed the original description of this taxon that, on the basis of the opinion 126 of the ICZN, they considered invalid. Finally, these authors assigned the ammonite attributed to N. telingaeformis by Reyment (1955) to the species Hoplitoides gibbulosus (von Koenen, 1897), and considered the specimens classified as $N$. cf. N.xetra, N.sp. 1 and N.sp. 2 by Freund and Raab (1969) as probable members of $N$. cephalotus. Zaborski (1987) and Chancellor et al. (1994) added two other taxa to the already large list of synonyms of $N$. cephalotus accepted by Kennedy and Wright (1979). Franciscoites suarezi EtayoSerna, 1979, known only by a small number of juvenile specimens, was considered as a possible synonym of $N$. cephalotus by both authors. N. transitorius Renz, 1982, was suggested as a probably conspecific form of $N$. cephalotus by Zaborski (1987), and was unequivocally included in the synonymy of the same species by Chancellor et al. (1994).

In fact, the original of A. telinga shows the typical features of the lectotype of $N$. cephalotus, including the characteristic lateral inflation of the adult body chamber. No distinction can therefore be made between these two taxa. In a similar way, observing the available images of the type of $A$. santonensis, this taxon does not seem distinguishable from $N$. cephalotus. In addition, the morphology and the ontogenetic development shown by the lectotype of $A$. xetra designated by Kennedy and Wright (1979) appear to indicate that it is a wide specimen of $N$. cephalotus. After studying the small type of $P$. africanus and the two types of $N$. gourguechoni in the MNHN, we have noticed that these ammonites possess, respectively, the typical features of the juvenile and of the compressed members of 
$N$. cephalotus. Likewise, the morphologies of the three new taxa proposed by Solger (1904) also seem to coincide with $N$. cephalotus. Specifically, the features of $N$. crassus are coincident with those of the more depressed specimens of $N$. cephalotus before losing ornamentation. The proportions and suture lines of $N$. telingaeformis and $N$. perovalis apparently also correspond to members of $N$. cephalotus. In addition to these morphological observations it should be mentioned that the only record of $N$. telingaeformis from the Iberian Trough is within the geographical and stratigraphical distribution attributed to $N$. cephalotus.

The types of $N$. transitorius are small specimens, still with constrictions, whose features coincide with those of the representatives of $N$. cephalotus in the early ontogenetic stages. Finally, it should be emphasised that the specimen assigned to $N$. telingaeformis by Reyment (1955) shows suture lines notably different from those of the members of Vascoceratidae, whereas the ammonites classified as $N$. cf. $N$. xetra, N. sp. 1 and N. sp. 2 by Freund and Raab (1969) seem to be representatives of $N$. cephalotus.

The relationship between $N$. cephalotus and $N$. xetriformis has caused much controversy. Kennedy and Wright (1979), and subsequently Robaszynski et al. (1982), Zaborski (1987) and Thomel (1992), among others, maintained that both taxa should be regarded as differentspecies on the basis of the more distant ribbing, which extends up to the adult body chamber, and the smaller size of $N$. xetriformis. However, these authors suggested that $N$. cephalotus and $N$. xetriformis could be two mere dimorphs. On the contrary, other authors, like Cobbanand Hook (1983), Kennedy and Cobban (1988), Cobban et al. (1989), Robaszynski et al. (1990) and Chancellor et al. (1994), considered that these two taxa may represent the macroconchs ( $N$. cephalotus) and the microconchs ( $N$. xetriformis) of the species of Courtiller. It has recently been observed by the authors of the present work that the persistent and striking ornamentation and the broad whorl section of the three original specimens of $N$. xetriformis, currently held in the $\mathrm{MNHN}$, make it easy to differentiate them from the lectotype of $N$. cephalotus. Nevertheless, many works have shown the wide morphological variability of $N$. cephalotus, in which $N$. xetriformis could probably be included as a mere dimorph. Therefore, the specimens classified as $N$. xetriformis, or morphologically very close to this taxon, although with doubts, have been included here in the synonymy of $N$. cephalotus.

Occurrence: this species has been identified in the lower and middle Turonian of France, southern India, Tunisia, Algeria, Cameroon, Madagascar, Spain, Syria, Israel, Morocco, the USA, Japan, Nigeria, Egypt, Portugal and, possibly, Mexico and Venezuela. The oldest records of $N$. cephalotus have been collected from the Pseudaspidoceras flexuosum zone of the USA, as noticed by Cobban and Scott (1972) and Kauffman et al. (1978). In other countries this species occurs in biostratigraphic units equivalent to the upper part of the Watinoceras devonense standard zone and to the M. nodosoides and Collignoniceras woollgari standard zones. In the Iberian Trough, although Wiedmann and Kauffman (1978) and Wiedmann (1979) assigned this species to their middle
Turonian zone $\mathrm{T} \mathrm{VI}$, we have demonstrated that the stratigraphical distribution of $N$. cephalotus in this region also comprises the lower Turonian M. nodosoides zone. Except for one, all the specimens of $N$. cephalotus come from the Outer Navarro-Cantabrian Platform and the North-Castilian Sector.

\section{Conclusions}

In the present work, newspecimens from the Iberian Trough have been described and assigned to the species F. catinus, F. tevesthensis, F. rudra, F. mortzestus sp. nov., F. superstes, F. pachydiscoides and N. cephalotus. Although all these taxa had already been cited, except for the logical exception of the new species, F. catinus and F. tevesthensis had never previously been properly classified nor illustrated for this palaeogeographical region. During the revision, it has been noted the presence of specimens that are attributable to F. bomba in the collections of the UT and the UCM. Therefore, it can be assumed that the family Vascoceratidae is represented, among others, by the genera Fagesia and Neoptychites in the Iberian Trough, where the species F.catinus, F.tevesthensis, F.rudra, F.mortzestus sp. nov., sp. nov., F. superstes, F. pachydiscoides, $N$. cephalotus and, probably, F. bomba have been properly identified.

Furthermore, the distribution of the members of the Vascoceratidae presented here has been determined (Fig. 11). Although one member of the genus Fagesia, attributed to F. catinus, has been collected in the Spathites (Jeanrogericeras) subconciliatus zone, the continuous occurrence of this group in this palaeogeographical region has been observed in the upper part of the Choffaticeras (Leoniceras) luciae subzone and the M. nodosoides zone. Tobe more precise, F. tevesthensis has been identified in the upper part of the Choffaticeras (Leoniceras) luciae subzone and the base of the M. nodosoides subzone. F. mortzestus sp. nov. and F. rudra have been obtainedinthe M.nodosoides subzone. Lastly, the species F. superstes has been identified in the upper part of the M. nodosoides subzone and in the Wrightoceras munieri subzone, and consequently its stratigraphically highest records seem to determine the end of the occurrence of Fagesia in the Iberian Trough.

Otherwise, the only species of Neoptychites identified in this palaeogeographical region, $N$. cephalotus, has been recorded in the $M$. nodosoides zone and levels attributed to the middle Turonian. The highest specimens of this genus can be considered as the latest members of the Vascoceratidae in the Iberian Trough.

In terms of the phylogeny of the group, one possible evolutionary lineage joining $F$. tevesthensis and F. superstes has been identified within the genus Fagesia (Fig. 11). It progressively becoming more involute and depressed, and less ornamented forms.

After observing the distribution of the Vascoceratidae in the Iberian Trough, three main evolutionary phases can be distinguished, as already pointed out by Barroso-Barcenilla and Goy (2005). The last one occurs subsequently to the successive dominances of the "primitive" Vascoceras and of 


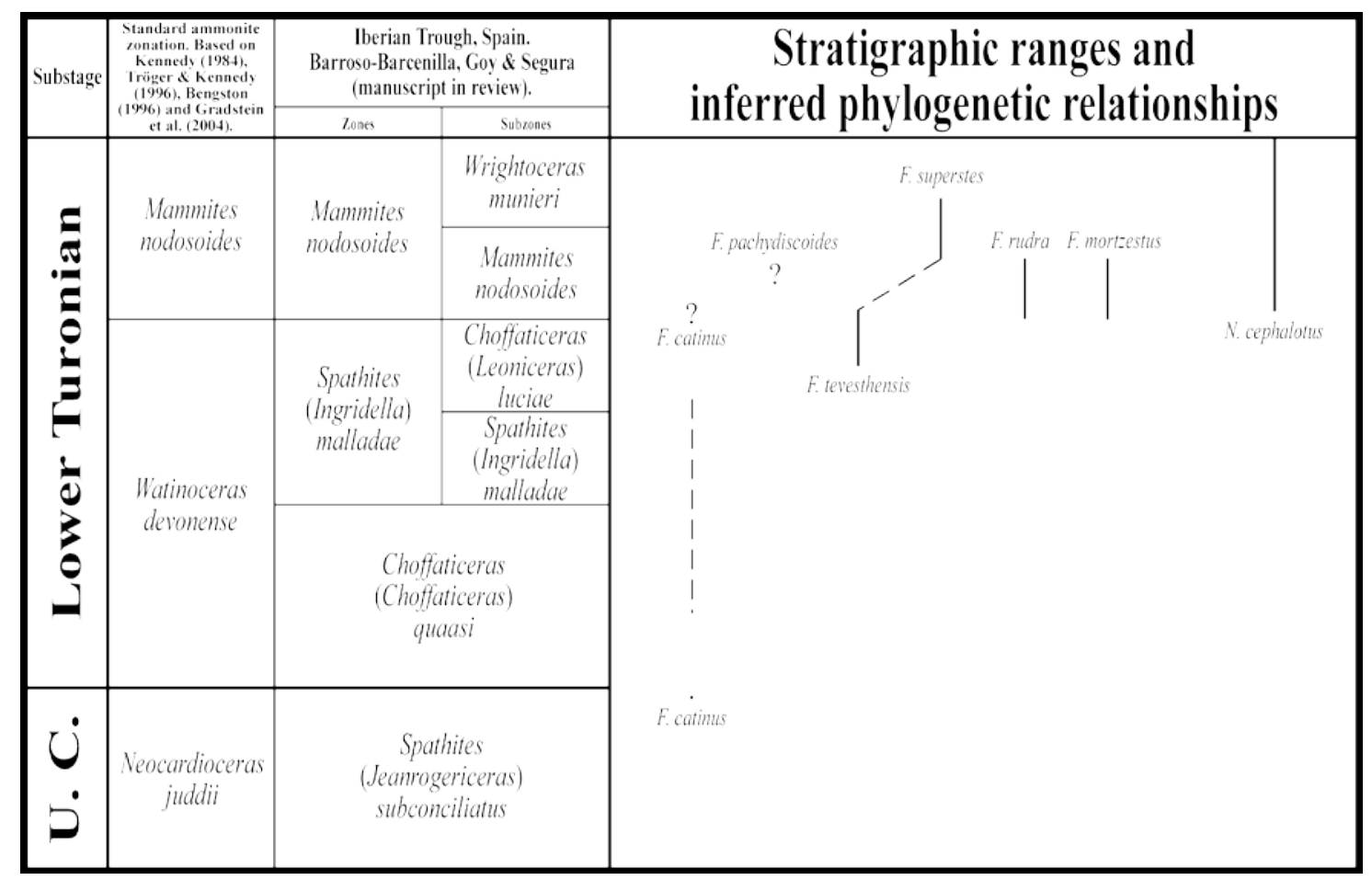

Fig. 11. Stratigraphical ranges of the species of Fagesia and Neoptychites identified in this work and their inferred phylogenetic relationships.

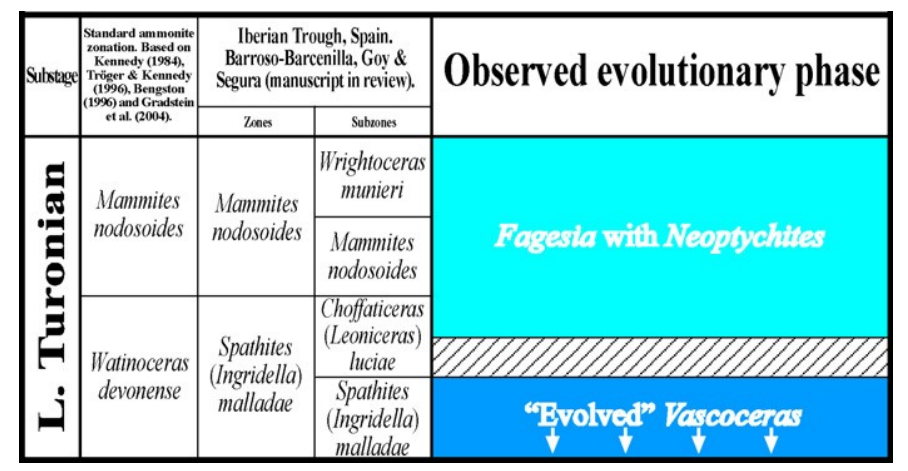

Fig. 12. Observed phase in the evolution of Vascoceratidae (Fagesia and Neoptychites) in the Iberian Trough.

the "evolved" Vascoceras, analysed in detail by BarrosoBarcenillaand Goy (manuscriptin review), and is characterised by the dominance of Fagesia and Neoptychites (Fig. 12). This phase has been identified in the upper part of the Choffaticeras (Leoniceras) luciae subzone, and mainly in the M. nodosoides zone of the lower Turonian. During this phase, species of the genera Fagesia and Neoptychites as F. tevesthensis, F. rudra, F. mortzestus sp. nov., F. superstes and N. cephalotus, represent the Vascoceratidae. This evolutionary phase seem not only to coincide with the evolutionary interval followed by the family in other palaeogeographical regions, but also by other groups, as indicated by Barroso-Barcenilla and Goy (2005).

\section{Acknowledgements}

The first author appreciates the help offered by $\mathrm{Dr}$ Alexander Liebau and Dr Hartmut Schulz from the Institut und Museum für Geologie und Paläontologie of the UT,
Germany; by Prof Dr Miguel Brandão and Mrs Joanna Pachucka from the Museu do Instituto Geológico e Mineiro de Lisboa, Portugal; and by Dr Annie Cornée, Dr Didier Merle, Dr Jean-Michel Pacaud and Prof Dr Jean-Paul Saint Martin from the Muséum National d'Histoire Naturelle de Paris, France, in order to study the types from the upper Cenomanian and lower Turonian which are held in their respective institutions. He also expresses his gratitude to Prof Dr William James Kennedy from the Oxford University Museum of Natural History, UK, and Mr Francis Amédro from Calais, France, for their valuable remarks concerning the identification of some of the specimens presented here.

We would like to thank Prof Dr Manuel Segura Redondo from the Universidad de Alcalá de Henares, Spain, for his help lending us some cephalopods belonging to his own collection and for his useful remarks about the Spanish Upper Cretaceous. Wealso want to express our gratitude for the excellent work carried out by Ignacio Meléndez Hevia, who collected and analysed some of the specimens herein described while working on his final project for graduation. Likewise, we want to thank Inmaculada Martínez Martínez, graduate in English Philology, and María del Mar Martínez Martínez, graduate in Translation and Interpretation, for their work as translators, as well as Carlos Alonso Recio, for his work as a photographer for the Departamento de Paleontología of the UCM, Spain. Wealso recognize the work of the reviewers of this manuscript, who have notably improved its original content.

This study has been carried out within the Project 01/1003/ 2003 of the Dirección General de Investigación of the Comunidad de Madrid, Spain, and the projects CGL 200501765/BTE of the Ministerio de Educación y Ciencia and 
PAI08-0204-1312 of the Junta de Castilla-La Mancha, and financed by these Spanish institutions and by the Social Fund of the European Union.

\section{References}

Adkins, W.S., 1931. Some Upper Cretaceous ammonites in western Texas. University of Texas Bulletin 3101, 35-72.

Amédro, F., Hancock, J.M., 1985. Les ammonites de l'Autoroute «l'Aquitaine », France (Turonien et Santonien). Cretaceous Research 6, 15-32.

Anderson, F.M., 1931. The genus Fagesiain the Upper Cretaceous of the Pacific Coast. Journal of Paleontology 5, 121-126.

Anderson, F.M., 1958. Upper Cretaceous of the Pacific coast. Geological Society of America, Memoir 71, 1-378.

Barber, W., 1957. Lower Turonian ammonites from north-eastern Nigeria. Geological Survey of Nigeria, Bulletin 26, 1-87.

Barroso-Barcenilla, F., 2004. Acanthoceratidae y zonación de ammonites del Cenomaniense superiory del Turoniense inferior en el Área de Puentedey, Cuenca Vasco-Cantábrica, España. Coloquios de Paleontología 54, 83-114.

Barroso-Barcenilla, F., 2006. Cefalópodos del Cenomaniense superior y del Turoniense inferior en el Surco Ibérico, España. PhD thesis, Universidad Complutense de Madrid (unpublished).

Barroso-Barcenilla, F., 2007. Revision and new data of the ammonite family Acanthoceratidae de Grossouvre, 1894, from the lower Turonian of the Iberian Trough, Spain. Palaeontographica, Abteilung A 280, 123-163.

Barroso-Barcenilla, F., 2008. Revisión de la terminología aplicada a los nautiloideos y ammonoideos postriásicos en español. Boletín de la Real Sociedad Española de Historia Natural, Sección Geológica 102, 121-145.

Barroso-Barcenilla, F., Goy, A., 2005. La familia Vascoceratidae en el Surco Ibérico, España, y otros ejemplos de adaptación de los ammonoideosalos medios someros epicontinentales. In: Bernáldez, E., Mayoral, E., Guerreiro, A. (Eds.), Libro de Resúmenes de las XXI Jornadas de la Sociedad Española de Paleontología. Sociedad Española de Paleontología, Sevilla, pp. 94-96.

Barroso-Barcenilla, F., Goy, A., 2007. Revision and new data of the ammonite family Pseudotissotiidae in the Iberian Trough, Spain. Geobios 40, 455487.

Barroso-Barcenilla, F., Goy, A., Segura, M., 2008. Ammonite zonation of the upper Cenomanian and Lower Turonian in the Iberian Trough, Spain. Newsletters on Stratigraphy 43.

Basse, E., 1931. Monographie paléontologique du Crétacé de la Province de Maintirano (Madagascar). Annales géologiques du service des mines, Madagascar 1-86.

Basse, E., 1939. Sur quelques mollusques Crétacés des Corbières Méridionales. Bulletin de la Société géologique de France 11 (5), 35-58.

Basse, E., 1940. Les céphalopodes crétacés des massifs côtiers syriens. Pt. 2. Notes etmémoires Haut-commissariat République française en Syrie et au Liban 3, 411-472.

Bengtson, P., 1979. A bioestratigrafia esquecida: avaliação dos métodos bioestratigráficos no Cretáceo Médio do Brasil. Anais da Academia Brasileira de Ciências 51,535-544.

Bengtson, P., 1983. The Cenomanian-Coniacian of the Sergipe Basin, Brazil. Fossils and Strata 12, 1-78.

Böse, E., 1920. On anewammonite fauna of the Lower Turonian of Mexico. University of Texas, Bulletin 1856, 173-257.

Brito, I.M., 1971. Contribução ao conhecimento dos cefalópodos cretácicos do Estado de Sergipe. Anais da AcademiaBrasileira de Ciências, Suplemento 43, 423-432.

Callapez, P.M., 1998. Estratigrafia e Paleobiologia do Cenomaniano-Turoniano: O significado do eixo da Nazaré-Leiria-Pombal. PhD thesis, Universidade de Coimbra. (unpublished).

Callapez, P.M., Ferreira, A., 2001. Fósseis de Portugal: Amonóides do Cretácico Superior (Cenomaniano-Turoniano). Museu Mineralógico e Geológico da Universidade de Coimbra, Coimbra.

Carretero-Moreno, M.A., 1982. Estudios paleontológicos del Cretácico de la Serranía de Cuenca y de la Cordillera Central. PhD thesis, Universidad Complutense de Madrid. (unpublished).
Chancellor, G.R., 1982. Cenomanian-Turonian ammonites from Coahuila, México. Bulletin of the Geological Institutions of the University of Uppsala, NS 9, 77-129.

Chancellor, G.R., Kennedy, W.J., Hancock, J., 1994. Turonian ammonites faunas from Central Tunisia. The Palaeontological Association. Special Papers in Palaeontology 50, 1-118.

Choffat, P.,1898. Recueil d'études paléontologiques sur la faune crétacique du Portugal. Espèces nouvelles ou peu connues. Mémoires de la Direction des travaux géologiques du Portugal 1, 41-86.

Cobban, W.A., Hook, S.C., 1983. Mid-Cretaceous (Turonian) ammonite fauna from Fence Lake area, west-central New Mexico. New Mexico Bureau of Mines and Mineral Resources, Memoir 41, 1-50.

Cobban, W.A., Hook, S.C., Kennedy, W.J., 1989. Upper Cretaceous rocks and ammonite faunas of southeastern New Mexico. New Mexico Bureau of Mines and Mineral Resources, Memoir 45, 1-137.

Cobban, W.A., Scott, G.R., 1972. Stratigraphy and ammonite fauna of the Graneros Shale and Greenhorn Limestone near Pueblo, Colorado. United States Geological Survey Professional Paper 645, 1-108.

Collignon, M., 1965. Atlas des fossiles caractéristiques de Madagascar (ammonites), XII, Turonien. Service Géologique, Tananarive, iv + 82 p.

Collignon, M., 1966. Les céphalopodes crétacés du bassin côtier de Tarfaya. Notes et mémoires du service des mines et de la cartegéologique du Maroc $175,7-148$.

Coquand, H., 1859. Synopsis des animaux et des végétaux fossiles observés dans la Formation crétacé du sud-ouest de la France. Bulletin de la Société géologique de France 16 (2), 945-1023.

Coquand, H., 1860. Description physique, géologique, paléontologique et minéralogique du département de la Charente, tome 2. Barlatier-Feissat et Demonchy, Marseille.

Courtiller, M.A., 1860. Description de trois nouvelles espèces d'ammonites du terrain crétacé des environs de Saumur et des ammonites Carolinus et Fleuriausianus a l'état adulte. Mémoires de la Société impériale d'agriculture, sciences et arts d'Angers 3, 246-252.

Courtiller, M.A., 1867. Les ammonites du Tuffeau. Annales de la Société linnéenne de Maine-et-Loire Angers 9, 1-8.

Diener, C., 1925. Ammonoidea neocretacea. In: Diener, C. (Ed.), Fossilium Catalogus (1: Animalia) Pars 29. W. Junk, Berlin, pp. 1-244.

Douvillé, H., 1912. Évolution et classification des Pulchelliidés. Bulletin de la Société géologique de France 11 (4), 285-320.

Eck, O., 1909. Bemerkungen über drei neue Ammoniten aus der oberen ëgyptischen Kreide. Sitzungsberichte der Gesellschaft für Naturforschender Freunde zu Berlin 3, 179-191.

Eck, O., 1914. Die Cephalopoden der Schweinfurthschen Sammlung aus der Obern Kreide Ägyptens. Zeitschrift der Deutschen Geologischen Gesellschaft 66, 179-216.

Etayo-Serna, F., 1979. Zonation of the Cretaceous of central Columbia by ammonites. Publicaciones Geológicas Especiales del Ingeominas 2, 1-186.

Faraud, M., 1940. Le genre Vascoceras dans le Turonien du Gard. Bulletin de la Société d'étude des sciences naturelles du Vaucluse 3/4,1-24.

Floquet, M., 1991. Laplate-formenord-castillane au Crétacé Supérieur (Espagne). Arrière-pays ibérique de la marge passive basco-cantabrique. Sédimentation et vie. Mémoires géologiques de l'université de Dijon 14, 1-925.

Floquet, M., Alonso, A., Meléndez, A., 1982. El Cretácico Superior de Cameros-Castilla. In: García, A. (Ed.), El Cretácico de España. Universidad Complutense de Madrid, Madrid, pp. 387-456.

Freund, R., Raab, M., 1969. Lower Turonian ammonites from Israel. The Palaeontological Association. Special Papers in Palaeontology 4, 1-83.

Gräfe, K.U., 1994. Sequence stratigraphy in the Cretaceous and Paleogene (Aptian to Eocene) of the Basco-Cantabrian Basin (N. Spain). Tübinger Geowissenschaftliche Arbeiten (A) 18, 1-418.

Gräfe, K.U., Wiedmann, J., 1993. Sequence stratigraphy in the Upper Cretaceous of the Basco-Cantabrian Basin (Northern Spain). Geologische Rundschau 82, 327-361.

Grossouvre, A. de, 1894. Recherches sur la craie supérieure. 2 Paléontologie. Les ammonites de la craie supérieure. Mémoires du Service de la Carte géologique détaillée de la France, $\mathrm{ii}+264 \mathrm{p}$.

Grossouvre, A. de, 1896. Sur le genre Neoptychites. Bulletin de la Société géologique de France 24, 86. 
Hook, S.C., Cobban, W.A., 1981. Late Greenhorn (Mid-Cretaceous) discontinuity surfaces, southwest New Mexico. New Mexico Bureau of Mines and Mineral Resources, Circular 180, 5-21.

Hyatt, A., 1903. Pseudoceratites of the Cretaceous. United States Geological Survey Monograph 44, 1-351.

Karrenberg, M., 1935. Ammoniten aus der Nordspanischen Oberkreide. Palaeontographica, Abteilung A 82, 125-161.

Kassab, A.S., 1994. Upper Cretaceous ammonites from the El Sheikh Fads-Ras Gharib Road, Northeastern Desert, Egypt. Neues Jahrbuch für Geologie und Paläontologie Monatshefte 1994, 108-128.

Kauffman, E.G., Cobban, W.A., Eicher, D., 1978. Albian through lower Coniacian strata, biostratigraphy, and principal events, Western interior United States. Annales du Muséum d'Histoire naturelle de Nice 4, xxiii.1xxiii.35.

Kennedy, W.J., 1986. Appendix 1, Ammonite biostratigraphy of the Albian to basal Santonian. In: Reyment, R.A., Bengtson, P.(Eds.), Events of the MidCretaceous, Final Report on results obtained by IGCP Project 58, 1974 1985. Physics and Chemistry of the Earth 16, pp. 129-182.

Kennedy, W.J., 1994. Lower Turonian ammonites from Gard (France). Proceedings of the 3rd Pergola International Symposium, Pergola, Italy, 1990. Palaeopelagos, Special Publication 1, 255-275.

Kennedy, W.J., Cobban, W.A., 1988. Mid-Turonian ammonite faunas from northern Mexico. Geological Magazine 125, 593-612.

Kennedy, W.J., Cobban, W.A., Hancock, J.M., Hook, S.C., 1989. Biostratigraphy of the Chispa Summit Formation at its type locality: a Cenomanian through Turonian reference section for Trans-Pecos Texas. Bulletin of the Geological Institutions of the University of Uppsala, NS 15, 39-119.

Kennedy, W.J., Hancock, J.M., 1978. The Mid-Cretaceous of the United Kingdom. Annales du Muséum d'Histoire naturelle de Nice 4, v.1-v.72.

Kennedy, W.J., Simmons, M.D., 1991. Mid-Cretaceous ammonites and associated microfossils from the central Oman Mountains. Newsletters on Stratigraphy 25, 127-154.

Kennedy, W.J., Wright, C.W., 1979. Vascoceratid ammonites from the type Turonian. Palaeontology 22, 665-683.

Kennedy, W.J., Wright, C.W., Hancock, J.M., 1987. Basal Turonian ammonites from west Texas. Palaeontology 30, 27-74

Koenen, A. von, 1897. Über Fossilen der unteren Kreide am Ufer des Mungo in Kamerun. Abhandlungen der Königlichen Gesellschaft der Wissenschaft zu Göttingen, Mathematikchen-Physikalische Klasse, NR 1, 1-48.

Kossmat, F., 1895. Untersuchungen über die Südindische Kreideformation. Beiträge zur Paläontologie und Geologie Österreich-Ungarns und des Orients 9, 97-203 (1-107).

Kossmat, F., 1897. Untersuchungen über die Südindische Kreideformation. Beiträge zur Paläontologie und Geologie Österreich-Ungarns und des Orients 11, 1-46 (108-153).

Küchler, T., 1998. Upper Cretaceous of the Barranca (Navarra, northern Spain); integrated litho-, bio-, and event stratigraphy. Part I: Cenomanian through Santonian. Acta Geologica Polonica 48, 157-236.

Kummel, B., Decker, J.M., 1954. Lower Turonian ammonites from Texas and Mexico. Journal of Paleontology 28, 310-319.

Lamolda, M.A., Gorostidi, A., Martínez, R., López, G., Peryt, D., 1997. Fossil occurrences in the Upper Cenomanian-Lower Turonian at Ganuza, Northern Spain: an approach to Cenomanian/Turonian boundary chronostratigraphy. Cretaceous Research 18, 331-353.

Lamolda, M.A., López, G., Martínez, R., 1989. Turonian integrated biostratigraphy in the Estella Basin (Navarra, Spain). In: Wiedmann, J. (Ed.), Cretaceous of the Western Tethys. Proceedings of the 3rd International Cretaceous Symposium, Tübingen 1987, pp. 145-159.

Leanza, A.F., 1967. Algunos ammonites nuevos ó poco conocidos del Turoniano de Colombia y Venezuela. Acta Geológica Lilloana 9, 189-213.

López, G., Santamaría-Zabala, R., 1992. Correlación entre las zonas de ammonites e inocerámidos de la parte de la Cuenca Navarro-Cántabra y la Plataforma Norcastellana. III Congreso Geológico de España y VIII Congreso Latinoamericano de Geología, Actas 1, pp. 524-528.

Luger, P., Gröschke, M., 1989. Late Cretaceous ammonites from the Wadi Qena area in the Egyptian Eastern Desert. Palaeontology 32, 355-407.

Mantell, G., 1822. The fossils of the South Downs, or illustrations of the geology of Sussex. L. Rolfe, London, $x v i+327 p$.
Martínez, R., 1982. Ammonoideos cretácicos del Prepirineo de la provincia de Lleida. Publicaciones de Geología de la Universidad de Barcelona 17.

Martínez, R., Lamolda, M.A., Gorostidi, A., López, G., Santamaría-Zabala, R., 1996. Bioestratigrafía integrada del Cretácico Superior (Cenomaniense Superior-Santoniense) de la región Vascocantábrica. Revista Española de Paleontología, Número Extraordinario, 160-171.

Matsumoto, T., 1959. Upper Cretaceous ammonites of California, Part I. Memoirs of the Faculty of Science of the Kyushu University, Serie D. Geology 8, 91-171.

Matsumoto, T., 1973. Vascoceratid ammonites from the Turonian of Hokkaido. Transactions and Proceedings of the Palaeontological Society of Japan, NS $89,27-41$.

Matsumoto, T., 1978. A record of Neoptychites from the Cretaceous of Hokkaido. Recent Researches in Geology 4, 196-207.

Matsumoto, T., Muramoto, K., 1978. Further notes on vascoceratid ammonites from the Turonian of Hokkaido, with notes on the early Turonian palaeogeography. Transactions and Proceedings of the Palaeontological Society of Japan, NS 109, 280-292.

Matsumoto, T., Obata, I., 1982. Some interesting acanthocerataceans from Hokkaido. Bulletin of the National Science Museum of Tokyo, Series C 8, 67-92.

Meister, C., Abdallah, H., 1996. Les ammonites du Cénomanien supérieur et du Turonien inférieur de la région de Gafsa-Chotts, Tunisie du Centre-Sud. Geobios 29 Supplément, 3-49.

Meister, C., Abdallah, H., 2005. Précision sur les successions d'ammonites du Cénomanien-Turonien dans la région de Gafsa, Tunisie du centre-sud. Revue de Paléobiologie 24, 111-199.

Meister, C., Alzouma, K., Lang, J., Mathey, B., Pascal, A., 1994. Nouvelles données sur les ammonites du Niger oriental (Ténéré, Afrique occidentale) dans le cadre de la transgression du Cénomanien-Turonien. Geobios 27, 189-219.

Meléndez-Hevia, I., 1984. Ammonoidea del Cenomaniense superior y Turoniense en el borde sur del Sistema Central, entre Tamajón y Somolinos (Guadalajara). PhD, Universidad Complutense de Madrid. (unpublished).

Mojica, J., Wiedmann, J., 1977. Kreide-Entwicklung und Cenomanien/Turonien-Grenze der mittleren Keltiberischen Ketten bei Nuévalos (Prov. Zaragoza, Spanien). Eclogae Geologicae Helvetiae 70, 739-759.

Orbigny, A. d', 1850. Prodrome de Paléontologie stratigraphique universelle des animaux mollusques et rayonnés, volume 2. Masson, Paris.

Peron, A., 1889. Description des mollusques fossiles des terrains crétacés de la région sud des Hauts-Plateaux de la Tunisie recueillis en 1885 et 1886 par M. Philippe Thomas. Exploration scientifique de la Tunisie. Masson, Paris, $\mathrm{xii}+103 \mathrm{p}$

Peron, A., 1896. Les ammonites du Crétacé Supérieur de l'Algérie. Mémoires de la Société géologique de France 17 (6), 1-24.

Peron, A., 1897. Les ammonites du Crétacé Supérieur de l'Algérie. Mémoires de la Société géologique de France 17 (7), 25-88.

Pervinquière, L., 1903a. Étude géologique de la Tunisie centrale. Carte Géologique de la Tunisie. De Rudeval, Paris, vii + $359 \mathrm{p}$

Pervinquière, L., 1903b. Ammonites cephalotus Courtiller, 1860. Palaeontologia Universalis, Centuria 1. Congrès Géologique International, Laval.

Pervinquière, L., 1907. Études de paléontologie tunisienne 1, Céphalopodes des terrains secondaires. Carte Géologique de la Tunisie. De Rudeval, Paris, v+ $438 \mathrm{p}$.

Powell, J.D., 1963a. Cenomanian-Turonian (Cretaceous) ammonites from Trans-Pecos Texas and northeastern Chihuahua, Mexico. Journal of Paleontology 37, 309-322.

Powell, J.D., 1963b. Turonian (Cretaceous) ammonites from northeastern Chihuahua, Mexico. Journal of Paleontology 37, 1217-1232.

Reeside Jr., J.B., 1923. A new fauna from the Colorado group of Southern Montana. United States Geological Survey Professional Paper 132, 25-31.

Renz, O., 1982. The Cretaceous ammonites of Venezuela. Maraven S.A., Caracas.

Reyment, R.A., 1955. The Cretaceous Ammonoidea of southern Nigeria and the Cameroons. Geological Survey of Nigeria, Bulletin 25, 1-112.

Riedel, L., 1932. Die Oberkreide von Mungofluss in Kamerun und ihre Fauna. Beiträge zur Geologischen Erforschung der Deutschen Schutzgebiete 16, $1-154$. 
Robaszynski, F. (Coord), Alcaydé, G., Amédro, F., Badillet, G., Damotte, R., Foucher, J.C., Jardiné, S., Legoux, O., Manivit, H., Monciardini, C., Sornay, J., 1982. Le Turonien de la région-type: Saumurois et Touraine. Stratigraphie, biozonations, sédimentologie. Bulletin des Centres de Recherches Exploration-Production Elf-Aquitaine 6, 119-225.

Robaszynski, F., Caron, F., Dupuis, C., Amédro, F., González Donoso, J.M., Linares, D., Hardenbol, J., Gartner, S., Calandra, F., Deloffre, R., 1990. A tentative integrated stratigraphy in the Turonian of Central Tunisia: formations, zones and sequential stratigraphy in the Kalaat Senan area. Bulletin des Centres de Recherches Exploration-Production Elf-Aquitaine 14, 213-384.

Roman, F., 1912. Coup d'œil sur les zones de Céphalopodes du Turonien du Vaucluse et du Gard. Congrès de Nîmes, 1912, Géologie et Minéralogie. Comptes Rendus de l'Association Française pour l'Avancement des Sciences, 1-15.

Santamaría-Zabala, R., 1991. Ammonoideos del Cretácico Superior de la Plataforma Nord-Castellana y parte de la Cuenca Navarro-Cántabra. Paleontología y Bioestratigrafía. PhD thesis, Universidad de Barcelona. (unpublished).

Santamaría-Zabala, R., 1992. Los ammonoideos del Cenomaniense Superior al Santoniense de la Plataforma Nord-Castellana y la Cuenca Navarro-Cántabra. Parte I. Bioestratigrafía y sistemática: Phylloceratina, Ammonitina (Desmocerataceae y Hoplitaceae) y Ancyloceratina. Treballs del Museu de Geología de Barcelona 2, 171-268.

Santamaría-Zabala, R., 1995. Los ammonoideos del Cenomaniense superior al Santoniense de la Plataforma Nord-Castellana y la Cuenca Navarro-Cántabra. Parte II. Sistemática: Acanthocerataceae. Treballs del Museu de Geología de Barcelona 4, 15-131.

Santamaría-Zabala, R., López, G., 1996. Aspectos bioestratigráficos de los ammonites e inocerámidos (Bivalvia) del Albiense Superior al Maastrichtiense de la provinciade Álava. RevistaEspañoladePaleontología, Número Extraordinario, 148-159.

Segura, M., García, A., García-Hidalgo, J., Carenas, B., 1993. The Cenomanian-Turonian transgression in the Iberian Ranges (Spain): depositional sequences and the location of the Cenomanian-Turonian boundary. Cretaceous Research 14, 519-529.

Segura, M., Wiedmann, J., 1982. Latransgresión del Cretácico Superior en el sector de Atienza-Sigüenza (Guadalajara, Cordillera Ibérica) y el significado de la fauna ammonitífera. Cuadernos de Geología Ibérica 8, 293-307.

Sharpe, D., 1855. Description of the fossil remains of Mollusca found in the Chalk of England 1, Cephalopoda. The Palaeontographical Society, Monograph, 27-36.

Solger, F., 1904. Die Fossilien der Mungokreide in Kamerun und ihre geologische Bedeutung, mit besonderer Berücksichtigung der Ammoniten. In: Esch, E., Solger, F., Oppenheim, P., Jaekel, O. (Eds.), Beiträge zur Geologie von Kamerun, II. Schweizerbart'sche Verlagsbuchhandlung, Stuttgart, pp. 85-242.

Spath, L.F., 1925. On Upper Albian Ammonoidea from Portuguese East Africa, with an appendix on Upper Cretaceous ammonites from Maputoland. Annals of the Transvaal Museum 11, 179-200.

Stoliczka, F., 1865. The fossil Cephalopoda of the Cretaceous rocks of southern India, Ammonitidae, with revision of the Nautilidae. Palaeontologia Indica 3, 107-154.

Taubenhaus, H., 1920. Die Ammoniten der Kreideformation Palästinas und Syriens. Zeitschrift des Deutschen Palästina-Vereins 43, 1-58.

Thomel, G., 1969. Sur quelques ammonites Turoniennes et Sénoniennes nouvelles ou peu connues. Annales de paléontologie (invertébrés) 55, 111-124.

Thomel, G., 1992. Ammonites du Cénomanien et du Turonien du sud-est de la France. Tome 2. Serre Éditeur, Nice.

Wiedmann, J., 1960a. Le Crétacé supérieur de l'Espagne et du Portugal et ses Céphalopodes. In: Roger, J. (Ed.), Colloque sur le Crétacé Supérieur Français. Comptes Rendus du 84ème Congrès National des Sociétés Savantes, Dijon 1959, pp. 709-764.

Wiedmann, J., 1960b. Zur Systematik jungmesozoischer Nautiliden. Palaeontographica, Abteilung A 115, 144-206.
Wiedmann, J., 1962. Ammoniten aus der Vascogotischen Kreide (Nordspanien). I. Phylloceratina, Lytoceratina. Palaeontographica, Abteilung A 118, 119-237.

Wiedmann, J., 1964. Le Crétacé supérieur de l'Espagne et du Portugal et ses Céphalopodes. Estudios Geológicos 20, 107-148.

Wiedmann, J., 1975a. Subdivisiones y precisiones bio-estratigráficas en el Cretácico Superior de las Cadenas Celtibéricas. In: Meléndez, B., Meléndez, F. (Eds.), Reunión de campo sobre el Cretácico de la Provincia de Cuenca, España, 1974. Actadel Primer Simposium sobreel Cretácico dela Cordillera Ibérica, Cuenca, pp. 135-153.

Wiedmann, J., 1975b. El Cretácico Superior del Picofrentes (Soria), Cadenas Celtibéricas (España). Boletín Geológico y Minero 86, 252 (20)-261 (29).

Wiedmann, J., 1979. Mid Cretaceous Events; Iberian Field Conference, 1977. Guide II Partie. Itinéraire géologique à travers le Crétacé moyen des Chaînes Vascogotiques et Celtibériques (Espagne du Nord). Cuadernos de Geología Ibérica 5, 127-214.

Wiedmann, J., Kauffman, G., 1978. Mid-Cretaceous biostratigraphy of northern Spain. Annales du Muséum d'Histoire naturelle de Nice 4, iii.1-iii.34.

Wiese, F., 1995. Das mittelturone Romaniceras kallesi-Event im Raum Santander (Nordspanien): Lithologie, Stratigraphie, laterale Veränderung der Ammoniten-Assoziationen und Paläobiogeographie. Berliner Geowissenschaftliche Abhandlungen E16, 61-77.

Wiese, F., 1996. Preliminary data on the Turonian ammonite biostratigraphy of the Liencres area (Province Cantabria, northern Spain). Berliner Geowissenschaftliche Abhandlungen E18, 343-352.

Wiese, F., 1997. Das Turon und Unter-Coniac im Nordkantabrischen Becken (Proviz Kantabrien, Nordspanien): Faziesentwicklung, Bio-, Event- und Sequenzstratigraphie. Berliner Geowissenschaftliche Abhandlungen E24 viii $+131 \mathrm{p}$.

Wiese, F., Wilmsen, M., 1999. Sequence stratigraphy in the Cenomanian to Campanian of the north Cantabrian Basin (Cantabria, N-Spain). Neues Jahrbuch für Geologie und Paläontologie Abhandlungen 212, 131-173.

Wilmsen, M., 1996. The Cenomanian of northern Cantabria (N. Spain): Facies development and sequential subdivision. Berichte/Reports GeologischPaläontologisches Institut und Museum der Universität Kiel 76, 181-187.

Wilmsen, M., 1997a. Some notes on the Cenomanian cephalopod fauna of the North Cantabrian Basin (northern Spain). Freiberger Forschungshefte C468, 319-331.

Wilmsen, M., 1997b. Das Oberalb und Cenoman im Nordkantabrischen Becken (Provinz Kantabrien, Nordspanien): Faziesentwicklung, Bio- und Sequenzstratigraphie. Berliner Geowissenschaftliche Abhandlungen E23, 1-167.

Wilmsen, M., 2000. Evolution and demise of a mid-Cretaceous carbonate shelf: the Altamira Limestones (Cenomanian) of northern Cantabria (Spain). Sedimentary Geology 133, 195-226.

Wilmsen, M., Wiese, F., 1996. The species Scaphites bituberculatus Santamaría-Zabala, 1992 (Cretaceous Ammonoidea) from the Upper Cenomanian of Tagle (Cantabria, northern Spain): geological setting, paleontology, and stratigraphic position. Acta Geologica Polonica 46, 89-98.

Wright, C.W., 1957. Ammonoidea. In: Moore, R.C. (Ed.), Treatise on Invertebrate Paleontology. Part L. Mollusca 4. Geological Society of America, Boulder, and University of Kansas Press, Lawrence, $x x i i+490 \mathrm{p}$.

Wright, C.W., 1996. Cretaceous Ammonoidea. In: Kaesler, R.L. (Ed.), Treatise on Invertebrate Paleontology. PartL. Mollusca 4. Geological Society of America, Boulder, and University of Kansas Press, Lawrence, xviii + 362p.

Wright, C.W., Kennedy, W.J., 1981. The Ammonoidea of the Middle Chalk. The Palaeontographical Society. Monograph 134, 1-148.

Yabe, H., 1904. Cretaceous Cephalopodafrom the Hokkaido, PartII, Journal of the College of Sciences. Imperial University of Tokyo 20, 1-45.

Zaborski, P.M.P., 1987. Lower Turonian (Cretaceous) ammonites from southeast Nigeria. Bulletin of the British Museum of Natural History, Geology Series 41, 31-66.

Zaborski, P.M.P., 1990. The Cenomanian and Turonian (mid-Cretaceous) ammonite biostratigraphy of north-eastern Nigeria. Bulletin of the British Museum of Natural History, Geology Series 46, 1-18. 